Southern Methodist University

SMU Scholar

Faculty Journal Articles and Book Chapters

Faculty Scholarship

2019

\title{
Defense Perspectives on Fairness and Efficiency at the International Criminal Court
}

Jenia I. Turner

Southern Methodist University, Dedman School of Law

\section{Recommended Citation}

Jenia I. Turner, Defense Perspectives on Fairness and Efficiency at the International Criminal Court, in Oxford Handbook on International Criminal Law (Kevin Jon Heller et al. eds.)

This document is brought to you for free and open access by the Faculty Scholarship at SMU Scholar. It has been accepted for inclusion in Faculty Journal Articles and Book Chapters by an authorized administrator of SMU Scholar. For more information, please visit http://digitalrepository.smu.edu. 


\title{
Defense Perspectives on Fairness and Efficiency at the International Criminal Court
}

\author{
Jenia Iontcheva Turner ${ }^{1}$
}

OXFORD HANDBOOK ON INTERNATIONAL CRIMINAL LAW (Kevin Jon Heller et al. eds.)

(forthcoming 2017)

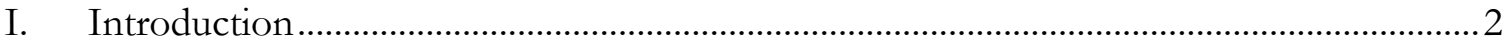

II. The Rise of Managerial Judging at International Criminal Courts ..................................... 4

III. Defense Views on Fairness and Efficiency at the ICC ................................................... 7

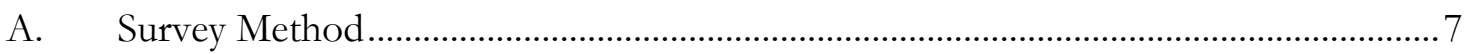

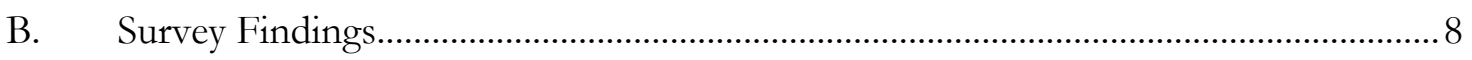

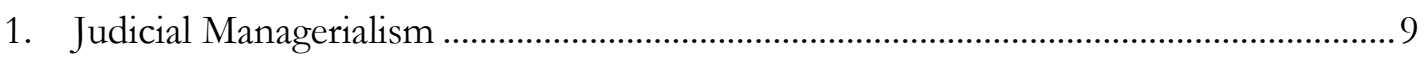

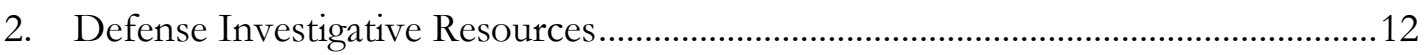

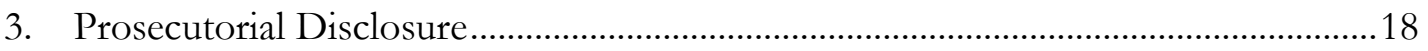

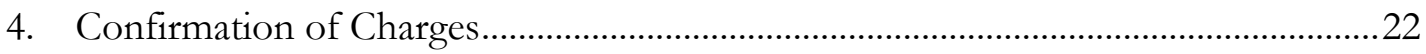

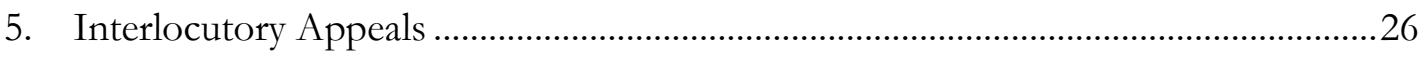

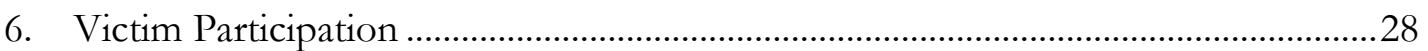

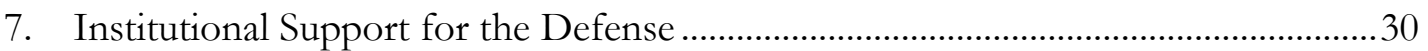

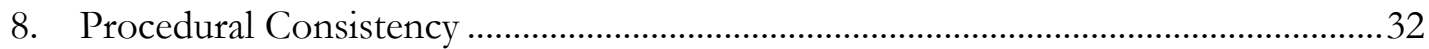

IV. The Future of Managerial Judging and Procedural Fairness at the ICC .......................33

\footnotetext{
1 Amy Abboud Ware Centennial Professor in Criminal Law, SMU Dedman School of Law. I thank the survey participants for sharing their observations with me and to Esteban Peralta Losilla and the Counsel Support Section at the ICC for agreeing to distribute the survey on my behalf. Thanks also go to Meg deGuzman, Megan Fairlie, Ken Gallant, Chris Jenks, Stephen Smith Cody, and participants in the University of Oslo PluriCourts conference on "Strengthening the Validity of International Criminal Tribunals," the 2016 Annual Meeting of the Southeast Association of Law Schools, and the 2016 ASIL International Criminal Law Interest Group Workshop for their comments. Finally, I am grateful to the SMU Law Faculty Excellence Fund for supporting the research for this chapter.
} 


\section{Introduction}

Over the last several years, the International Criminal Court (ICC) has come under increasing pressure to expedite its proceedings and do more with fewer resources. ${ }^{2}$ The Assembly of States Parties has created special working groups to examine how to streamline the criminal process, and judges at the court have responded with their own study of the same question. ${ }^{3}$ The notion that the Court's proceedings are too lengthy and not properly managed is broadly shared among ICC observers, participants, and stakeholders. ${ }^{4}$

Efficiency is an important goal for international criminal courts, for a number of reasons. It ensures defendants' right to a speedy trial, promotes victims' interest in closure, conserves limited resources, and helps provide justice in as many cases as possible with the resources available. Yet an unrelenting pursuit of efficiency can interfere with other values of the international criminal process, such as the protection of individual rights and the search for truth. ${ }^{5}$ This tradeoff was observed at the International Criminal Tribunal for the former Yugoslavia (ICTY). Under pressure by donors to speed up proceedings and cut costs in the 2000s, ICTY judges introduced various "managerial" reforms, which limited oral evidence in favor of written statements, restricted the parties' time for examining witnesses, discouraged interlocutory appeals, and failed to provide sufficient time and resources for defense investigations. ${ }^{6}$ Scholars and even some ICTY judges found that these procedural reforms at times gave undue priority to judicial economy over fairness, equality of arms, and a thorough exploration of the facts.

\footnotetext{
2 See Sergey Vasiliev, The Structure and Management of International Criminal Trials' (Guest Lecture, ICC Office of the Prosecutor, The Hague, 26 March 2015).

${ }^{3}$ See, eg, 'ASP 14: How can ICC trials be more efficient?' (Coalition for the ICC, 24 November 2015, <https://ciccglobaljustice.wordpress.com/2015/11/24/asp14-how-can-icc-trials-be-more-efficient.> [accessed 3 November 2016].

${ }^{4}$ See Guénaël Mettraux et al., Expert Initiative Report on Promoting Effectiveness at the International Criminal Court (2014) 83 (Expert Initiative Report); Håkan Friman, 'Trial Procedures_With a Particular Focus on the Relationship Between the Proceedings of the Pre-Trial and Trial Chambers' in Carsten Stahn (ed), The Law and Practice of the International Criminal Court (OUP 2015) 909, 915-31; John Jackson and Yassin M'Boge, 'The Effect of Legal Culture on the Development of International Evidentiary Practice: From the "Robing Room" to the "Melting Pot" (2013) 26 Leiden J Intl L 947, 965; War Crimes Research Office, Expediting Proceedings at the International Criminal Court (2011) 33 (WCRO Expediting Proceedings Report).

5 Vasiliev (n 2) 18.

${ }^{6}$ Geert-Jan Alexander Knoops, 'The Dichotomy Between Judicial Economy and Equality of Arms Within International and Internationalized Criminal Trials: A Defense Perspective' (2005) 28 Fordham Intl LJ 1566, 1589; Maximo Langer, The Rise of Managerial Judging in International Criminal Law, (2004) 53 Am J Comp L 835, 874; Vasiliev (n 2) 18; Richard Vogler, 'Making International Criminal Procedure Work: From Theory to Practice,' in Ralph J. Henham and Mark Findlay (eds), Exploring the Boundaries of International Criminal Justice (Ashgate 2011)105, 110; see also Maximo Langer and Joseph W. Doherty, 'Managerial Judging Goes International, But Its Promise Remains Unfulfilled' (2011) 36 Yale J Intl L 241, 260 (finding that the managerial reforms instituted at the ICTY increased rather than decreased the length of proceedings). For the application of managerialism to the English criminal justice system, see Jenny McEwan, 'From Adversarialism to Managerialism: Criminal Justice in Transition’ (2011) 31 Legal Studies 519, 528-34.

${ }^{7}$ Prosecutor v. Milosevic (Dissenting Opinion of Judge David Hunt), ICTY Appeals Chamber, IT-02-54-AR73.4 (21 October 2003) [20]-[22]; Patricia M. Wald, 'To "Establish Incredible Events by Credible Evidence": The Use of Affidavit Testimony in Yugoslavia War Crimes Tribunal Proceedings' (2001) 42 Harvard Intl L J 535, 550-52; Langer (n 6) 903-04; Knoops (n 6) 1590.
} 
Judges are beginning to introduce similar reforms at the ICC, and more are likely to come in the near future. ${ }^{8}$ In the effort to expedite proceedings, ICC judges have tried to restrict certain prosecutorial actions, such as late disclosure, overbroad charging documents, and phased investigations, which are seen as contributing to delays. ${ }^{9}$ Thus chambers have tried to direct the timing of prosecutorial investigations and to shape charges brought by prosecutors. ${ }^{10}$ Some pretrial judges have also taken an interventionist approach to disclosure, requiring prosecutors to submit in-depth analysis charts explaining the documents disclosed $^{11}$ and demanding that both parties submit to Chambers all the documents exchanged during disclosure, to give judges the information necessary to manage the pretrial process.

It remains an open question whether judicial managerialism has also circumscribed defense activities. A few defense attorneys have commented on their experiences with certain aspects of ICC procedure, such as the confirmation of charges and disclosure. ${ }^{12}$ But no one has examined systematically how judges' procedural decisions have affected the defense at the ICC. Has judicial managerialism limited defense opportunities to present and examine witnesses, to review disclosure, or to file interlocutory appeals? ${ }^{13}$ Have cost concerns led to restrictions on defense investigations? ${ }^{14}$ Have Chambers urged defense

\footnotetext{
${ }^{8}$ Regulation 54 of the ICC Regulations notes the various orders that Trial Chambers can issue to "streamline trials as far as possible," "to avoid, as much as possible, long and detailed, and possibly insufficiently insubstantiated, indictments with a multitude of alternative or cumulative charges that would have to be decided separately in the course of trial," "to limit the average length of trials as far as possible," and "to prevent, wherever possible, trials from being hijacked by the defendant." Hans-Peter Kaul, 'Construction Site for More Justice: The International Criminal Court After Two Years’ (2005) 2 Am J Intl L 370, 376. For a suggestion that managerialism is likely to grow in importance, see Vasiliev (n 2) 13-14; see also Expert Initiative Report (n 4) 8-43.

9 See, eg, Hans-Peter Kaul, 'The ICC of the Future' (2012) 45 Studies in Transnational Legal Policy 99, 110-11 (identifying "phased investigations" and "across the board redactions" of documents as a key source of delay); see also WCRO Expediting Proceedings Report (n 4) 8-10 (identifying prosecutorial disclosure and investigative activity as sources of delay).

${ }^{10}$ For example, judges have refused to confirm cumulative charges with respect to the actus reus, and they have prohibited charges resting on alternative modes of liability for the same crime.

11 Through these charts, judges have required the prosecution to relate each piece of information disclosed to one or more of the elements of crimes charged. See Johan D. van der Vyver, 'Time Is of the Essence: The InDepth Analysis Chart in Proceedings Before the International Criminal Court' (2012) 48 Crim L Bull Art I. In Bemba, the Pre-Trial Chamber required the defense to submit an in-depth analysis chart for its evidence, too. Prosecutor v. Jean-Pierre Bemba Gombo, (Decision on the Disclosure of Evidence by the Defence) Pre-Trial Chamber III, ICC-01/05-01/08-31 (5 December 2008) [ๆ9]-[ 110$].$

12 See, eg, Natacha Fauveau-Ivanovic, 'Quelle réalité pour les droits de la défense au sein de la Cour pénale internationale?' (2014) 5 Revue des droits de l'homme 2; Karim A A Khan and Caroline Buisman, 'Sitting on Evidence? Systemic Failings in the ICC Disclosure Regime-Time for Reform,' in Carsten Stahn (ed), The Law and Practice of the International Criminal Court (OUP 2015) 1029; Karim A.A. Khan and Anand A. Shah, 'Defensive Practices: Representing Clients Before the International Criminal Court' (2013) 76 L \& Contemporary Problems 191.

${ }^{13}$ See Jackson and M'Boge, (n 4) 966 (noting that some ICC defense attorneys have expressed concern about judges relying too heavily on written statements rather than oral witness testimony and therefore preventing the defense from fully presenting or challenging witness accounts).

${ }^{14}$ Cf Knoops (n 6) 1567 (observing this effect of efficiency measures at the ICTY).
} 
attorneys to disclose their case early on ${ }^{15}$ or to settle any aspects of the case with the prosecution $^{16}$

To begin an exploration of these questions, I surveyed ICC defense attorneys about their views on the Court's procedures. The survey asked broad questions about the fairness and expeditiousness of ICC proceedings, as well as more targeted questions about the use of managerial techniques by judges and the effect of these techniques on the defense.

Responses to the survey showed that, at least at present, defense attorneys do not perceive judicial managerialism as an impediment to adequate representation at the ICC. While attorneys expressed several concerns about procedural unfairness at the Court, they did not believe that judges' preoccupation with efficiency was the cause for the unfairness. Respondents complained about insufficient financial and institutional support for defense work, but they tended to place responsibility for these decisions on the Registry and States Parties, not on judges. ${ }^{17}$ Respondents did express concerns about certain judicial decisions on disclosure, charging, interlocutory appeals, and victim participation. ${ }^{18}$ But for the most part, defense attorneys did not believe that an emphasis on efficiency drove the results in these decisions. Rather, the attorneys thought that judges failed to give sufficient weight to defendants' rights and deferred too much to victims' interests.

The chapter analyzes these defense perspectives against the background of scholarly commentary and judicial decisions. In most respects, defense attorney views are consistent with comments on ICC procedure by outside observers and supported by the Court's record. It is beyond the scope of this chapter to verify the accuracy of each defense allegation. But on the whole, defense critiques are in line with external assessments of the ICC’s procedures.

While academic writings on managerial judging have tended to assume that the practice undercuts defense rights, survey responses suggest a more complex dynamic at the ICC. Respondents opined that certain judicial efforts to expedite proceedings-demanding earlier disclosure, filtering out charges more aggressively, and restricting victim participation-could favor defense rights.

It is difficult to predict the precise measures that ICC judges might take to expedite proceedings. Judges might limit the defense's ability to question witnesses, restrict defense investigations, and impose heavier disclosure obligations on the defense. But survey responses suggest that managerialism need not always harm defense rights. Defense attorneys could leverage the court's emphasis on expeditiousness to advocate for greater judicial regulation of prosecutorial activities.

\section{The Rise of Managerial Judging at International Criminal Courts}

\footnotetext{
15 See, eg, Khan and Shah (n 12) 223-24 (arguing that the confirmation hearing and associated disclosure and managerial practices have forced defense attorneys to reveal their strategy early on, allowing the prosecution to adjust its case for trial and potentially interfering with the presumption of innocence and the defendant's right to remain silent).

${ }^{16}$ Cf Langer (n 6) 875 (noting that this was a feature of managerial judging at the ICTY).

${ }_{17}$ See infra Part III.B.2.

18 See infra Part III.B.
} 
The concept of managerial judging was first used by American scholars to describe trends in American civil procedure. ${ }^{19}$ As Judith Resnik noted in her famous article on the topic, in the late 1970s, U.S. judges took on a more activist stance in civil cases and were "not only adjudicating the merits of issues presented to them by litigants, but also [...] meeting with parties in chambers to encourage settlement of disputes and to supervise case preparation." ${ }^{20}$ Before too long, scholars in other countries observed similar trends in criminal cases. $^{21}$

Maximo Langer was the first to apply the term "managerial judging" to describe procedural reforms at international criminal courts. ${ }^{22}$ Langer describes managerial judging as a practice under which 'the court, with the parties' assistance, wields [procedure as a device] to expedite process." ${ }^{23}$ He contrasts managerialism with the more traditional judicial demeanor in adversarial and inquisitorial systems:

Unlike the passive and uninformed court of the adversarial system, the managerial court gets information about the case very early in the process in order to actively pressure the parties to reach factual and legal agreements and accelerate their pre-trial investigations and trial cases. But unlike the court of the inquisitorial system that actively investigates the truth, the managerial court is active to make sure that the parties do not delay proceedings. ${ }^{24}$

Other scholars also observed that judges were using procedural measures to streamline proceedings in international criminal cases. ${ }^{25}$ Although most discussions of this trend have focused on the ICTY and ICTR, Vasiliev has noted that managerial judging has spilled over into other international criminal courts as well. ${ }^{26}$

Judges at the ICTY and ICTR pursued efficiency through a wide range of procedures. Status conferences "streamlined the proceedings and armed the Trial Chambers with information, enabling them to exercise greater control over their cases." ${ }^{27}$ Judges also “establish[ed] a work plan that sets forth the parties' obligations and the dates upon which

\footnotetext{
${ }^{19}$ Robert F. Peckham, 'The Federal Judge as a Case Manager: The New Role in Guiding a Case from Filing to Disposition' (1981) 69 California L Rev 770, 770; Judith Resnik, 'Managerial Judges' (1982) 96 Harvard L Rev 374, 374-80; William W. Schwarzer, 'Managing Civil Litigation: The Trial Judge's Role' (1978) 61 Judicature 400, 401-02.

${ }^{20}$ Resnik (n 19) 376-77.

${ }^{21}$ See, eg, McEwan (n 6) 522; New Zealand Law Commission, Criminal Pre-Trial Processes: Justice Through Efficiency (2005) < http://www.nzlii.org/nz/other/nzlc/report/R89/R89.pdf> accessed 4 November 2016; P Johnson and MF Latham, 'Criminal Trial Case Management: Why Bother?' (2011), <http://www.aija.org.au/Criminal\%20Justice\%20201120

2011/Papers/Latham\&Johnson.pdf> accessed 4 November 2016. For analysis of continued judicial passivity in U.S. criminal cases, see Darryl K. Brown, 'The Decline of Defense Counsel and the Rise of Accuracy in Criminal Adjudication' (2005) 93 California L Rev 1585, 1632; but cf Nancy J. King and Ronald F. Wright, 'The Insivible Revolution in Plea Bargaining: Managerial Judging and Judicial Participation in Negotiations' (2016) 95 Texas L Rev 325.

${ }^{22}$ Langer (n 6) 836.

23 ibid 836.

24 ibid.

${ }^{25}$ See, eg, Nancy Amoury Combs, 'Legitimizing International Criminal Justice: The Importance of Process Control' (2012) 33 Michigan J Intl L 321, 359; Vasiliev (n 2) 10-11; Wald (n 7) 549.

26 Vasiliev (n 2) 12; see also Fauveau-Ivanovic (n 12) 2, 7.

27 Combs (n 25) 330; Langer (n 6) 888.
} 
they must be met." 28 Critically, judges demanded early and broad disclosure of evidence in order to equip the parties and the court with information to resolve the case more swiftly. To curb lengthy indictments and lengthy trials, judges also "invite[d] the Prosecutor to reduce the number of counts charged and the number of crime sites or incidents comprised within the charges." 29

At trial, judges restricted the number of witnesses called and the time allowed for examination and cross-examination. ${ }^{30}$ Judges also tried to accelerate the process by permitting more liberal use of written evidence. ${ }^{31}$ Throughout the process, they also used formal and informal rewards and sanctions to encourage the parties to agree on as many issues as possible and even to negotiate the outcome of the case. ${ }^{32}$ Finally, judges limited the opportunity to appeal preliminary issues as a way to move cases along. ${ }^{33}$

Commentators have expressed concern about the effect that managerial judging has had on the fairness of the trial and the search for truth. Langer has argued that "there is a tension between judicial activism to expedite proceedings on the one hand and fairness and truth-determination on the other. For instance, this judicial activism may have created problems of impartiality, and the use of written statements has probably worsened the truthdetermination ability of ICTY trials." "34 Knoops has asserted that Tribunals' emphasis on efficiency disproportionately burdened the defense and undermined equality of arms. ${ }^{35}$ Vasiliev has also observed the potential conflict between managerial judging and defense interests:

[T] he defence may not be forced to cooperate with the managerial court (or sanctioned for its failure to do so fully) by admitting facts, by giving up or disclosing defences before hearing the prosecution evidence, by reaching agreements on evidence (Rule 69), or by not presenting evidence it deems material to its case. In general, the defence has no apparent incentives to expedite the process, as opposed to delaying it. In most scenarios, it will opt for a 'contest-everything' tactic, which helps divert the adversary's resources from the core issues of personal responsibility and linkage evidence to the investigation and presentation of crime-base evidence. ${ }^{36}$

Even some ICTY judges have denounced specific managerial practices as inconsistent with procedural fairness. ${ }^{37}$

A few commentators have acknowledged that, in some cases, "shorter proceedings may benefit the defendant" 38 and that managerial judging could also cut into prosecutorial

${ }^{28}$ Combs (n 25) 330; Langer (n 6) 888.

${ }^{29}$ Vasiliev (n 2) 11.

${ }^{30}$ Combs (n 25) 330; Langer (n 6) 889.

31 Langer (n 6) 899-900.

32 ibid 892-93, 898-99.

33 ibid 901-02.

34 ibid 908 n 370.

35 Knoops (n 6) 1580.

36 Vasiliev (n 2) 18.

${ }^{37}$ Milosevic (Dissenting Opinion of Judge Hunt) (n 7) [20]-[22]; Wald (n 7) 550-52.

${ }^{38}$ Langer (n 6) 908 n 370. 
independence. ${ }^{39}$ But as a general matter, managerial judging is seen primarily as a burden on the defense.

In recent years, ICC judges have come under a similar pressure to expedite proceedings Efficiency has become a mantra at Assembly of States Parties meetings, and judicial and acadmic study groups have discussed measures that the court could take to streamline the process.

ICC judges already have various tools they need to expedite proceedings. They can hold status conferences to set filing schedules, discuss questions about disclosure, regulate the evidence to be presented, and set time limits on arguments. ${ }^{40}$ They can encourage the parties to settle factual or legal issues and dismiss or recharacterize the charges pursued by the prosecutor. They can also restrict the issues on which the parties can obtain interlocutory appeals.

In fact, judges have already begun using some of these tools, particularly at the pretrial stage. To streamline proceedings, they have closely regulated disclosure, ${ }^{41}$ required the prosecution (and sometimes the defense) to produce summaries of evidence to be disclosed and charts indicating the relationship between each piece of evidence and the charges, ${ }^{42}$ and rejected or reshaped a number of charges. ${ }^{43}$ Some have even attempted to regulate the timing of prosecutorial investigations. ${ }^{44}$ So far, accounts of judicial managerialism have focused on measures that have encumbered the prosecution more than the defense. But as the court remains under pressure to expedite proceedings, it is worth examining whether and how managerial practices may also have affected the defense.

\section{Defense Views on Fairness and Efficiency at the ICC}

\section{A. Survey Method}

At present, we know little about the impact that managerial practices might have on defense representation at the ICC. To begin gathering information on this question, I conducted an online survey of ICC defense attorneys in May-June 2016. The survey consisted of 23 questions, which were estimated to take 10-15 minutes to answer. The questions were in English, but French-speaking attorneys were told they could respond in

\footnotetext{
${ }^{39}$ Vasiliev (n 2) 18.

${ }^{40}$ ICC Rules of Procedure and Evidence 2002 (ICC RPE), ICC-ASP/1/3 and Corr.1, r 121; ICC Regulations of the Court 2004, ICC-BD/01-01-04, reg 54.

${ }^{41}$ Alex Whiting, 'Disclosure Challenges at the International Criminal Court' in Carsten Stahn (ed), The Law and Practice of the International Criminal Court (OUP 2015) 1007, 1027-28.

42 Van der Vyver (n 11) 48.

43 War Crimes Research Office, The Confirmation of Charges Process at the International Criminal Court: a Critical Assessment and Recommendations for Change (2015) 44 (WCRO Confirmation of Charges Report); Expert Initiative (n 4) 82.

44 Alex Whiting, 'Dynamic Investigative Practice at the International Criminal Court' (2013) 76 Law \&

Contemporary Problems 163, 167.
} 
French. ${ }^{45}$ To encourage participation, the survey was confidential and did not ask for the participants' names or nationalities. ${ }^{46}$ No other incentives were provided for participation.

Based on ICC filings and a research of public records, I identified and emailed 53 attorneys who had practiced at the ICC to request their participation. The list included primary and associate counsel, but also a few duty counsel, ad hoc counsel, one legal consultant, and one legal assistant. ${ }^{47}$ In addition, the Counsel Support Section (CSS) at the Registry, which maintains a list of counsel and their email addresses (but could not share these with me because of privacy concerns) agreed to send the solicitation on my behalf. This solicitation went out to 69 practicing ICC counsel and associate counsel who had intervened at the ICC, yielding a few additional responses. In total, 82 attorneys received a solicitation either directly from me or from the CSS. Of those 82 attorneys, 18 substantially completed the survey, ${ }^{48}$ which represents a response rate of $22 \%$. Because the sample was not random, selection bias may have affected the survey results. This survey should be viewed as a preliminary examination of defense views at the ICC and should be supplemented by follow-up studies.

The eighteen survey respondents have diverse legal backgrounds. Twelve have practiced in a common-law/ adversarial jurisdiction, five in a civil-law/ inquisitorial jurisdiction, and one in a mixed system. Because the survey questions were in English, the results somewhat overrepresent English-speaking, common-law attorneys and may not fully reflect the distinct perspectives of Francophone and civil-law attorneys. ${ }^{49}$

The level of experience among respondents varied as well. All but one had at least five years of experience in international criminal law, at the domestic or the international level, and eleven had over fifteen years of experience. Five had worked at the ICTY, thirteen at the ICTR, and 2-4 at each of the SCSL, ECCC, and the STL. ${ }^{50}$ Just under half of the respondents had practiced international criminal law in different capacities, as prosecutors, judges, legal officers, academics, or victim's representatives. The level of experience at the ICC also varied. Most respondents had handled one or two cases at the ICC, but a few had handled three or more. A large majority had handled matters at the pretrial stage, a smaller majority had done so at trial, and just over a third had handled matters on appeal. Roughly 91\% of respondents had recent experience representing clients at the ICC (from 2014 until present), but a majority had also defended ICC cases as early as 2003-11.

\section{B. Survey Findings}

\footnotetext{
45 Solicitation letters to those attorneys included a paragraph in French encouraging responses in French. ${ }^{46}$ Respondents were given the option, at the end of the survey, to provide their name and email to be contacted for further information. A few respondents provided their contact information, which has been kept confidential.

47 There were thirteen recipients who fell into that group (ad hoc or duty counsel; legal consultant; or legal assistant).

${ }^{48}$ Because respondents were not required to answer each question in order to move forward with the survey, some of them occasionally skipped one or more questions. This explains why some questions in the tables reproduced here have less than 18 responses. Twenty-three respondents began the survey, but five of them completed only a third of the survey, so these responses were not included in the analysis.

49 Three attorneys responded partially or fully in French.

${ }^{50}$ None had worked at the East Timor Special Panels.
} 


\section{Judicial Managerialism}

On the whole, respondents did not believe that the ICC had adopted a managerial approach to procedure or sacrificed fairness for efficiency. However, a large majority of the respondents expressed other concerns about equality of arms and procedural fairness at the court. Respondents complained that the court-particularly the Registry, under pressure by the States Parties - failed to provide the defense with sufficient resources and institutional support to allow for adequate investigation and trial preparation. Respondents also expressed concerns about judicial approaches to disclosure, the confirmation of charges, victim participation, and interlocutory appeals.

One of the first substantive survey questions in the survey asked respondents to select one or more labels that best describe the procedural system at the ICC. The results are reproduced in Table 1 below. Notably, only two respondents chose "managerial/efficiencydriven" as an appropriate label. Most picked "a mix of adversarial and inquisitorial" as the most fitting description. The second most popular label, chosen by more than half of respondents, was "victim-oriented." 51

\section{Table 1. Defense Categorization of ICC Procedural System.}

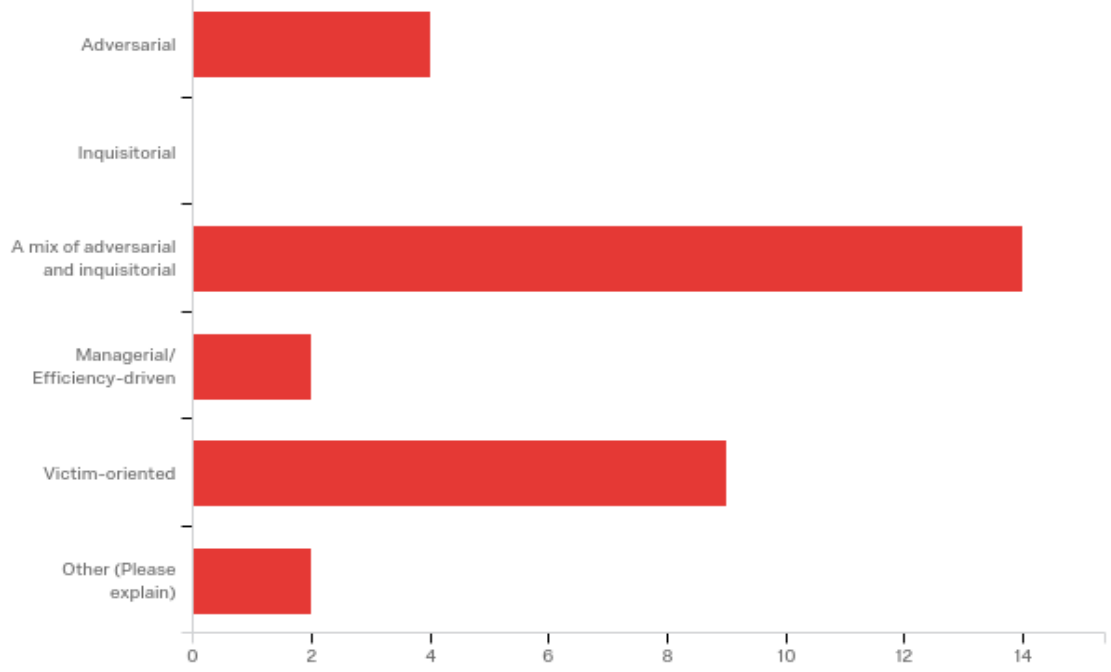

The survey next asked defense attorneys to indicate whether they had experienced certain procedural actions that unduly limited defense rights or interests. Specifically, the question asked whether the court had taken one of the following measures: 1) unduly restricted the defendant's right to make a statement; 2) unduly limited the defense's ability to investigate; 3) unduly limited the defense's ability to present defense witnesses; 4) unduly limited the defense's ability to question adverse witnesses; 5) unduly limited the defense's ability to review evidence disclosed by the prosecution; 6) unduly limited the defense's ability to file interlocutory appeals; 7) rejected any of the respondents' motions as "frivolous" or "baseless"; or 8) described defense tactics as "delay tactics"? Respondents were also given space and prompted to elaborate on their responses if they so wished.

\footnotetext{
${ }^{51}$ See Table 1.
} 
The most common restrictions reported were limits on the ability to investigate $(55.5 \%)$, limits on the ability to adequately review evidence disclosed by the prosecution $(64.7 \%)$, and limits on the ability to file interlocutory appeals $(60 \%) \cdot{ }^{52}$ Only a minority of respondents had experienced the other restrictions listed in the survey.

Table 2. Defense Experiences of Procedural Restrictions by the Court

\begin{tabular}{|c|c|c|c|c|c|}
\hline Question & Yes & & No & & Total \\
\hline $\begin{array}{l}\text { Unduly limited your client's right to make a statement (Please } \\
\text { explain if you wish.) }\end{array}$ & $23.53 \%$ & 4 & $76.47 \%$ & 13 & 17 \\
\hline $\begin{array}{l}\text { Unduly limited your ability to investigate on behalf of your client } \\
\text { (Please explain if you wish.) }\end{array}$ & $55.56 \%$ & 10 & $44.44 \%$ & 8 & 18 \\
\hline $\begin{array}{l}\text { Unduly limited your ability to present defense witnesses (Please } \\
\text { explain if you wish.) }\end{array}$ & $28.57 \%$ & 4 & $71.43 \%$ & 10 & 14 \\
\hline $\begin{array}{l}\text { Unduly limited your ability to question adverse witnesses (Please } \\
\text { explain if you wish.) }\end{array}$ & $33.33 \%$ & 5 & $66.67 \%$ & 10 & 15 \\
\hline $\begin{array}{l}\text { Unduly limited your ability to adequately review evidence } \\
\text { disclosed by the prosecution (apart from legitimate redactions for } \\
\text { witness protection) (Please explain if you wish.) }\end{array}$ & $64.71 \%$ & 11 & $35.29 \%$ & 6 & 17 \\
\hline $\begin{array}{l}\text { Unduly limited your ability to file an interlocutory appeal (Please } \\
\text { explain if you wish.) }\end{array}$ & $60.00 \%$ & 9 & $40.00 \%$ & 6 & 15 \\
\hline $\begin{array}{l}\text { Rejected a motion as "frivolous" or "baseless"? (Please explain if } \\
\text { you wish.) }\end{array}$ & $40.00 \%$ & 6 & $60.00 \%$ & 9 & 15 \\
\hline $\begin{array}{l}\text { Described a tactic you have taken in the course of your } \\
\text { representation as a "delay tactic"? (Please explain if you wish.) }\end{array}$ & $35.71 \%$ & 5 & $64.29 \%$ & 9 & 14 \\
\hline
\end{tabular}

The survey also asked respondents to compare ICC procedures to those at other international criminal courts (to the extent that respondents had the relevant experience or knowledge). A majority of respondents thought that the ICC imposed the restrictions mentioned above more frequently than did other international criminal courts. At the same time, most respondents did not find that this made the ICC process more expeditious. Among those who had a basis of comparison, most thought that the pace of ICC proceedings was either about the same or slower than that of the ICTY and ICTR. ${ }^{53}$

When asked to compare the fairness of ICC procedure to that of other international criminal courts, one-third of respondents noted that it was as fair as ICTY procedure. Onefifth of respondents thought the ICC was less fair than the ICTY; none thought the ICC was fairer than the ICTY. ${ }^{54}$ Judgment was more mixed in comparing ICC and ICTR procedures-about 18\% thought that the ICC was fairer, while $23.5 \%$ thought the ICTR was fairer, and another $23.5 \%$ thought the two courts were similar in fairness. ${ }^{55}$ The ICC was seen as fairer than the ECCC by those who had a basis for comparison, while views about the fairness of the ICC vis-à-vis the STL and SCSL were mixed.

In response to a question about judicial activism, 64\% defense respondents stated that ICC judges are as active as they should be. Only one respondent thought judges should

\footnotetext{
52 See Table 2.

53 A couple of respondents did, however, believe that ICC proceedings were faster than the STL and SCSL.

${ }^{54}$ Roughly $47 \%$ of the respondents said they did not know which court was fairer.

55 Roughly $35 \%$ of respondents said they did not know which court was fairer.
} 
be less active, and four respondents believed that judges should be more active, with one suggesting that " $[t]$ hey should be better trained to manage proceedings consistent with basic fair trial guarantees." ${ }^{\prime 56}$ The lack of complaint about judicial intervention is particularly striking given that close to two-thirds of respondents hail from adversarial systems, where judges remain passive in criminal cases.

As some of the open-ended responses explained, judicial activism could be good or bad, depending on how it is used:

This is not an easy question as each court appears to have different approaches. Some are unduly active, while some much less so.... Again, the Confirmation Hearings are an odd animal and one may have thought the court would be more active-i.e. imaginative and investigative-but it is really a rubber stamp if there is a suggestion of adequate evidence being present. Having said that, in the Ruto /Kenyatta cases four suspects were not confirmed [sic]. So not a complete waste of time. ${ }^{57}$

Passivity or activism of the judges depends on the system of the proceeding (adversarial-passive or inquisitorial -active). An active judge in an adversarial system is not acceptable and vice versa. You have to choose and ICC does not choose! That is the problem. ${ }^{58}$

No problem if good judges are active, but it really is problematic if bad judges think they should actively manage all types of things. ${ }^{59}$

Another measure frequently mentioned as a feature of managerialism is an effort by judges to encourage the parties to enter into factual stipulations or to negotiate the charges or sentence. ${ }^{60}$ At the ICC, negotiations between the parties are permitted, but they seem to have occurred in only one case so far. ${ }^{61}$ Judges do not appear to have attempted to encourage the prosecution and defense to settle cases or stipulate to facts. ${ }^{62}$ According to most respondents, judges have also not demanded overly broad disclosure by the defense-a feature of managerialism that is often used to encourage negotiations and expedite the proceedings. ${ }^{63}$

Finally, most respondents agreed with the proposition that judges should take steps to expedite the process at the ICC. A majority $(61.5 \%)$ of respondents were open to the idea

\footnotetext{
56 Respondent \# 20.

57 Respondent \# 10.

${ }^{58}$ Respondent \# 15.

${ }^{59}$ Respondent \# 18.

${ }^{60}$ Langer (n 6) 879; McEwan (n 6) 527.

${ }^{61}$ The Court accepted its first admission of guilt in $A l$ Mabdi in 2016, but this remains an exceptional case. Prosecutor v. Al Mahdi, Judgment and Sentence, Trial Chamber VIII, ICC-01/12-01/15-171 (27 September 2016).

${ }^{62}$ None of the respondents indicated that this was already happening, even though the survey included a question whether judges should be promoting such negotiations. In $A l M a b d i$, no evidence emerged to suggest that judges encouraged an admission of guilt or otherwise participated in the negotiations. Alex Whiting, "The Significance of the ICC's First Guilty Plea,' Just Security, 23 August 2016, https://www.justsecurity.org/32516/significance-iccs-guilty-plea/. For a discussion of judicial encouragement of plea bargaining and factual stipulations to expedite proceedings, see, eg, McEwan (n 6) 525.

${ }^{63}$ Langer (n 6) 897; McEwan (n 6) 523.
} 
of judges promoting negotiations between the parties about the sentence or the charges. Most were also open to judges taking other measures - such as filtering out unwarranted charges at the confirmation stages, issuing judgments more quickly, and ensuring earlier and broader disclosure — to speed up proceedings. ${ }^{64}$

In short, defense attorneys do not believe that judges have been unduly interventionist or have sacrificed defense rights for the sake of efficiency. A review of ICC decisions that use the terms "efficiency," "judicial economy," and "expeditious" confirms that so far, judges have not allowed concerns about expeditiousness to undermine defense rights. There appears to be no correlation between the use of one of these terms and a decision against the defense. ${ }^{65}$ Chambers seem to be as likely to find for the defense as they are for the prosecution when efficiency, expeditiousness, or judicial economy is mentioned as a factor relevant to the decision. Finally, Chambers have largely refrained from using certain terms, such as "frivolous" and "delay tactic," to describe defense actions. ${ }^{66}$ This is also consistent with defense perceptions that judges are not using informal sanctions to prod the parties to speed up the process.

\section{Defense Investigative Resources}

Although respondents did not believe that judicial management of the proceedings has negatively affected defense representation at the ICC, they did complain about the underfunding of the defense as a result of cost concerns.

Like the international criminal tribunals and hybrid courts that preceded it, the ICC is in principle committed to ensuring equality of arms between defense and prosecution. Like its predecessors, however, it has interpreted equality of arms to mean procedural equality, not equality of resources. ${ }^{67}$ The parties are to be placed in "a procedurally equal position to make their case during the whole course of the trial." ${ }^{68}$ While international criminal procedure does not guarantee equality of resources, the right to a fair trial ensures that defendants receive "adequate" time and facilities to prepare a defense. ${ }^{69}$ Therefore, if the

\footnotetext{
${ }^{64} 58 \%$ said that judges should take other measures to expedite proceedings, while $42 \%$ said that judges should not do so.

65 A review of a random sample of 34 ICC procedural decisions that use the terms "efficiency," "judicial economy," or "expeditious" confirms that so far, judges have not let concerns about efficiency undermine defense rights. There appears to be no correlation between the use of one of these terms and a decision against the defense. Out of 34 decisions reviewed, a concern for expediting the proceedings was material to the outcome of 11 decisions. In 5 of these decisions, a concern for expediting the proceedings (or efficiency or judicial economy) favored the defense, in 4 decisions, the same concern favored the prosecution, and in 2 decisions, it favored both the prosecution and the defense (as against the victim's representatives).

${ }^{66}$ Judges never used the term "delay tactic" and used "frivolous" quite rarely, roughly 40 times.

${ }^{67}$ See Charles C. Jalloh and Amy DiBella, 'Equality of Arms in International Criminal Law: Continuing Challenges' (2013) in William A. Schabas, Yvonne McDermott, and Niamh Hayes (eds) The Ashgate Research Companion to International Criminal Law: Critical Perspectives (Aldershot: Ashgate, 2013) 251, 253.

${ }^{68}$ International Bar Association, Fairness at the International Criminal Court 19 fn 9 (2011) (quoting Stefania Negri, 'The Principle of "Equality of Arms" and the Evolving Law of International Criminal Procedure' (2005) 5 Intl Crim L Rev 513, 513.

${ }^{69}$ Rome Statute art 67(1)(b).
} 
defense is deprived of essential investigative resources or access to evidence, this may render the proceedings fundamentally unfair and warrant a stay of the proceedings. ${ }^{70}$

Most defense respondents stated that the ICC had at times unduly limited their ability to investigate. As a few open-ended responses indicated and an independent review of court records confirms, these restrictions were imposed primarily by the Registry and not by Chambers. ${ }^{71}$ A majority of those surveyed further stated (in response to a different question) that the court had not provided defense counsel with sufficient resources to represent clients.

Table 3: Has the ICC generally provided you with sufficient resources to adequately represent your client?

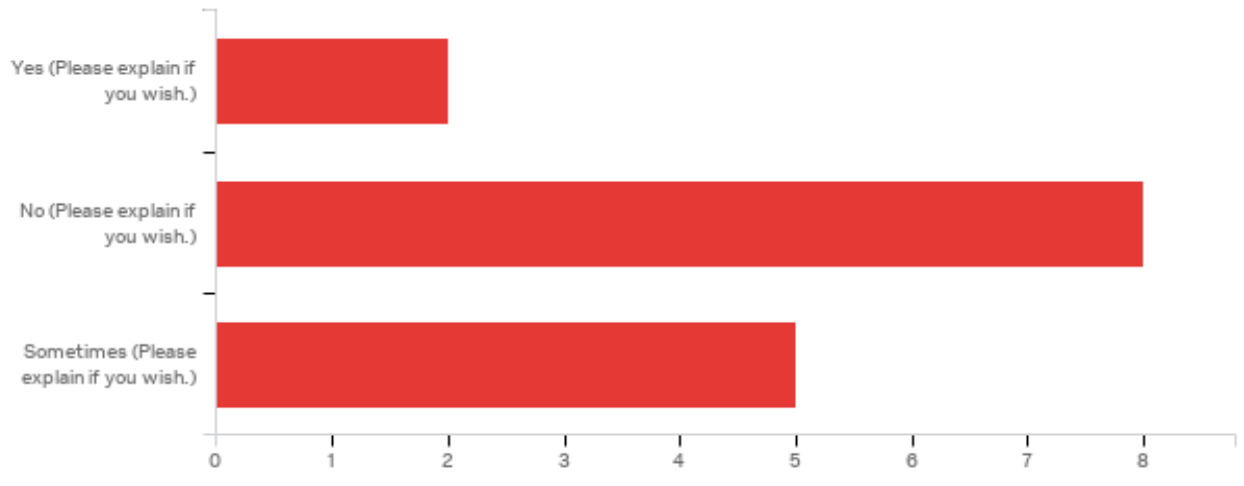

Open-ended responses elaborated on the types of resource restrictions imposed. While only one respondent criticized the level of remuneration for attorneys under the legal aid system, ${ }^{72}$ several complained that the Registry does not allocate sufficient staffing resources to meet the demands of complex cases.

\footnotetext{
70 See Prosecutor $v$. Thomas Lubanga Dyilo (Decision on the consequences of non-disclosure of exculpatory materials covered by Article 54(3)(e) agreements and the application to stay the prosecution of the accused, together with certain other issues raised at the Status Conference on 10 June 2008), Trial Chamber I, ICC01/04-01/06 (13 June 2008) [77]-[80], [91].

71 See, eg, Respondent \# 10 ("In the Reg 55 proceedings the Registry did not grant permission to investigate i.e pay for investigations - until the court itself had decided the issue that would make such investigations necessary. I can't say the court - i.e. Trial Chamber - limited me.”). It is possible, therefore, that the number of attorneys who believe they did not have sufficient resources to investigate may be higher. Some attorneys may have answered "no" to the question whether "the Court" limited their ability to investigate because they interpreted the term to include only the Chambers.

72 But see Respondent \# 9 (advocating reform of the legal aid system to pay counsel and their assistants better) (translated from French). For a public statement criticizing the level of payment, see David Hooper, 'Response to the Discussion Paper "Review of the ICC Legal Aid System"” (2012) 14 <http://www.iccnow.org/ documents/8212_D_Hooper_Q_C_response_legal_aid.doc $>$ accessed 28 June 2016. For a discussion of remuneration of counsel compared to remuneration of prosecutors, see International Criminal Court, Assembly of States Parties, Registry's Single Policy Document on the Court's Legal Aid System (Twelth Session, 2013) 11 < https://asp.icc-cpi.int/iccdocs/asp_docs/ASP12/ICC-ASP-12-3-ENG.pdf > accessed 4 November 2016 (discussing reduction of monthly counsel salaries from $€ 10,832$ to $€ 8,221$, with a possible maximum of $€ 10,687$ to compensate for professional charges; salaries for associate counsel are lower); Coalition for the International Criminal Court, Legal Representation Team, Comments and Recommendations on the 'Discussion paper on the Review of
} 
To provide context for this criticism, it is worth examining briefly the ICC's legal aid scheme. Before trial and during appeal, legal aid presumptively allocates funds for three defense team members: principal counsel, a legal assistant, and a case manager ${ }^{73}$ During trial, the defense team also receives funds for an additional "associate" counsel. ${ }^{74}$ The Registry may allocate additional staffing resources if the complexity of the case warrants it. ${ }^{75} \mathrm{~A}$ few respondents complained, however, that the Registry did not always approve funds for the staff needed to help with case preparation. ${ }^{76}$ As one respondent opined, " $[1]$ nflexible, formal budgets with fixed sums do never properly reflect the needs of counsel and put them from the beginning in a[n] unfair and limited position." 77

Several defense motions challenging Registry decisions on legal aid highlight the concern about staffing needs. ${ }^{78}$ In Lubanga, Ntaganda, and Katanga, the defense challenged staffing allocations made by the Registry at different points in the proceedings. In Lubanga, the defendant's first counsel, Jean Flamme, had to withdraw for health reasons just before the case was to be transferred from the Pre-Trial to the Trial Chamber. The replacement counsel-to-be, Catherine Mabille, demanded that the Registrar increase staffing on the case before she would accept appointment. Although the Registrar eventually largely acquiesced to Ms. Mabille's demands, the dispute delayed the proceedings for months. ${ }^{79}$

the ICC Legal Aid System' (2012)

<http://www.coalitionfortheicc.org/documents/Legal_Aid_review_comments.pdf >.

73 Registry's Single Policy Document (n 72) 10.

74 ibid 10.

75 ibid 15.

${ }^{76}$ See Respondent \# 10 ("In the Reg 55 proceedings the Registry did not grant permission to investigate -i.e pay for investigations - until the court itself had decided the issue that would make such investigations necessary. I can't say the court - i.e. Trial Chamber - limited me."); Respondent \# 19 (stating that the court "first rejected request for mission to question a witness, then rejected request to send full staff there" and arguing that "more staff [is] needed"); Respondent \# 23 (complaining that the court "provid[ed] grossly inadequate resources to enable me conduct appropriate investigations" and that " $\mathrm{t}]$ he budgetary allocations are arbitrary, grossly inadequate and payments and reimbursement of expenses incurred by counsel are either not paid or paid after several months going to years, if ever"); Respondent \# 6 (complaining of "lack of resources" and "administrative red tape"); Respondent \# 14 ("Defence teams do not have as many logistical resources at various levels. They are not considered ICC staff so they do not receive the same benefits and protections as staff. .. . Those on legal aid have to make numerous continuing requests for funding which makes job security hard to guarantee.”). But cf Respondent \# 10 (“In practice whenever I asked for more (and I concede I was careful in my demands given the initial indication of there being little funding) I got it. I don't think I was limited unduly by budget. But I could have been. In fact, it was almost as if we were designing the legal aid system. The scheme the ICC had put in place was wholly misplaced and it had to react to the practicalities that we were able to present.")

${ }_{77}$ Respondent \# 22; see also Prosecutor $v$. Ntaganda (Reasons for Review of Registrar's Decision on Defence Resources), Trial Chamber VI, ICC-01/04-02/06-389 (29 October 2014) [39]-[41]; Prosecutor v. Dominic Ongwen (Public Redacted Version of "Defence Submissions in Advance of the 23 May 2016 Status Conference"), Trial Chamber IX, ICC-02/04-01/15-439-Red2 (18 May 2016) [21].

78 The defense can challenge Registry decisions pursuant to Regulation 83(4).

${ }^{79}$ International Bar Association, Monitoring Report: International Criminal Court (2007) 17

$<$ http://www.ibanet.org/

Document/Default.aspx?DocumentUid=2D2681A9-0EEE-42AD-9A2D-DC2F3DB168C0 $>$ accessed 4 November 2016. 
The dispute resurfaced, however, after the Registry cut legal aid for the defense team for the period after closing arguments and before final judgment. ${ }^{80}$ Attorneys argued that the cutback violated Lubanga's fair trial rights because the defense needed to maintain a legal team to help with an eventual appeal, should one be needed. The Trial Chamber agreed and overruled the Registry's decision. ${ }^{81}$ Despite this decision in favor of Lubanga's defense, the same dispute between the Registry and the defense arose again in Katanga after closing arguments, and Chambers stepped in once more to restore legal aid. ${ }^{82}$

In Ntaganda, counsel challenged the Registry's refusal to allocate more than six months of salary for a second legal assistant to help at trial. ${ }^{83}$ The Chamber agreed with the defense that a second legal assistant should be funded for the duration of the trial. In reversing the Registry, the Chamber noted that the decision to deny funding was not supported by reasons and was inconsistent with the Registry's stated legal aid policy. ${ }^{84}$

A number of survey respondents also voiced concerns that they did not receive sufficient support for field investigations. The Court's legal aid system sets a budget for investigations at $€ 73,006$ per team. ${ }^{85}$ This is estimated to cover a total of about ninety days of investigations, including the salary of one professional investigator, one resource person in the field, daily allowance for the period, and travel costs of up to $€ 13,000 .{ }^{86}$ In addition, defense teams can be reimbursed for miscellaneous and travel expenses of up to $€ 3,000$ per month. Miscellaneous expenses include office supplies, translation of documents gathered in investigations, and solicitation of preliminary expert advice. ${ }^{87}$ Counsel may request additional resources, and the Registry will evaluate the request on a case-by-case basis, based on factors such as the number of charges filed, the number of victims participating in the case, and the number of additional witnesses called by the prosecution and the victims' representatives. ${ }^{88}$

While the budget scheme allows for funding increases to accommodate the practical demands of each case, several respondents noted that, in practice, support for investigations

\footnotetext{
80 The Registry refused to remunerate members of the legal team other than principal counsel on the case for the period after closing arguments and before judgment. Prosecutor $v$. Lubanga (Decision Reviewing the Registry's Decision on Legal Assistance for Mr. Lubanga), Trial Chamber I, ICC-01/04-01/06-2800 (30 August 2011)

[13].

${ }^{81}$ Lubanga (n 80) [63].

82 Prosecutor v. Katanga \& Chui (Transcript of Oral Order), Trial Chamber II, ICC-01/04-01/07-T-341-ENG (18 June 2012) [19]-[24].

83 After one counsel stepped down and a new counsel was appointed after the confirmation of charges, the new counsel, Stephane Bourgon, requested funds for a second legal assistant (which had previously been provided during the confirmation of stages proceedings). The Registry authorized funds for a second legal assistant for only a 6-month period. Defense counsel argued that the limited pay period would prevent the defense from hiring highly qualified assistants and that, in any event, given the complexity of the case and the extensive preparation necessary for trial, the defense would need a second legal assistant for more than a six-month period. Ntaganda (n 77) [13]-[17].

84 Ntaganda (n 77) [43].

${ }^{85}$ Registry's Single Policy Document (n 72) 11.

86 ibid 11.

$87 \mathrm{ibid} 25$. Once an expert is approved and requested to give testimony by the Chamber, the expert's fees and expenses are covered by a separate fund for the Victims and Witnesses Unit. $I d$.

88 ibid 11; Regulations of the Court (n 40) reg 83(3).
} 
has been insufficient. ${ }^{89}$ Again, these limitations were imposed by the Registry, not the judges. A few respondents also faulted the Registry for not approving certain investigative missions. ${ }^{90}$ In some cases, even when the Registry did eventually approve requests for additional investigation funds, the unpredictability of the funding frustrated the defense. ${ }^{91}$

These concerns have been echoed in public comments by defense attorneys. Reacting to a $23 \%$ cut in the defense budget for 2015, for example, defense attorney Nick Kaufman publicly criticized the inadequate funding of defense investigations. He complained that while the prosecution can plan its investigative activities in advance, "[ $\mathrm{t}]$ he defence... has to request permission from the Registry for every procedural step. This is a wholly unacceptable state of affairs ...." ${ }^{92}$ He elaborated that:

The institutionalised prejudice towards the defence exists and is ignored. By way of example, apart from the cost of a flight ticket and a basic living allowance, defence investigations are never funded in advance and mission expenses are reimbursed with a delay of several months. As a result, defence lawyers are forced to fund missions including witness expenses, food and accommodation - out of their own pocket. Just recently, I had to advance a loan of 1000 euros to my own legal assistant in order to prevent him from exceeding his overdraft while on mission in Ghana. ${ }^{93}$

Finally, Kaufman expressed his concern that "the underlying trend is a progressive cut in defence salaries and defence investigative resources." 94

Other attorneys have also gone on record to protest insufficient funding for defense investigations. ${ }^{95}$ Defense attorneys have noted that ICC funding falls below that provided by the ICTY and ICTR, even though ICC investigations tend to require greater financial and

\footnotetext{
${ }^{89}$ Respondent \# 19 ("first rejected request for mission to question a witness, then rejected request to send full staff there. . . "); Respondent \# 23 ("This has been done by providing grossly inadequate resources to enable me conduct appropriate investigations.").

90 See, eg, Respondent \# 10 ("In the Reg 55 proceedings the Registry did not grant permission to investigate i.e pay for investigations - until the court itself had decided the issue that would make such investigations necessary. I can't say the court - i.e. Trial Chamber - limited me.”); Respondent \# 19 (stating that the court "first rejected request for mission to question a witness, then rejected request to send full staff there" and arguing that "more staff [is] needed"); Respondent \# 23 (complaining that the court "provid[ed] grossly inadequate resources to enable me conduct appropriate investigations" and that " $t]$ he budgetary allocations are arbitrary, grossly inadequate and payments and reimbursement of expenses incurred by counsel are either not paid or paid after several months going to years, if ever").

${ }^{91}$ See Respondent \# 10 ("In practice whenever I asked for more (and I concede I was careful in my demands given the initial indication of there being little funding) I got it. I don't think I was limited unduly by budget. But I could have been. In fact, it was almost as if we were designing the legal aid system. The scheme the ICC had put in place was wholly misplaced and it had to react to the practicalities that we were able to present."); cf Respondent \# 14 ("Defence teams do not have as many logistical resources at various levels. .. . Those on legal aid have to make numerous continuing requests for funding which makes job security hard to guarantee."). 92 Sophie van Leeuwen, “Totally Unacceptable”: ICC Defence Counsel Budget Cuts Criticised' (Justice Hub, 15 December 2014) < https://justicehub.org/article/totally-unacceptable-icc-defence-counsel-budget-cutscriticised $>$ accessed 27 June 2016.

93 ibid.

94 ibid.

${ }^{95}$ Hooper (n 72) 13-17; ICC Office of Public Counsel for the Defence, Internal Memorandum from XavierJean Keïa to Esteban Peralta Losilla, 'OPCD Analysis/Response to Legal Aid Proposals' (31 January 2012) 7-8 $<$ http://www.icc now.org/documents/2012_01_31-_Legal_aid_proposal-OPCD_FV_4_.pdf>.
} 
logistical support. ${ }^{96}$ For example, because of a prohibition on witness proofing at the ICC (which did not exist at the ICTY or ICTR), defense counsel have to interview any potential witnesses in the field. ${ }^{97}$ Furthermore, ICC counsel, "unlike its counterparts at the ad hoc and hybrid courts and tribunals, will not have the benefit of a large and experienced defense bar with extensive and broad substantive knowledge of the conflict in question and practical advice on planning and conducting investigations on the ground." ${ }^{98}$ Defense attorneys must "build [their] defense team from the ground up in every respect [and t] he learning curve will be a steep one...." For For those reasons, ICC attorneys have argued that they need administrative and financial support even more than attorneys at the ad hoc international tribunals did. ${ }^{100}$

It is important to note that, in a few cases, such as those concerning high-powered Kenyan officials, defendants were able to afford private counsel and bankroll thorough defense investigations. As one respondent noted, "[t]he Defence in the Kenya Cases has been privately funded. The success of the Defence in Kenya shows that of course budget matters!" Furthermore, the Kenyan government not only did not stand in the way of defense activity, but likely facilitated it. ${ }^{101}$ The position of the Kenya defense teams, however, is relatively unique at this point in the court's work. Most ICC defense attorneys have not been able to count on either extensive resources or the unconditional support of domestic authorities.

Academic commentary echoes survey responses about the challenges of defense investigations. Scholars have discussed the special difficulties that international criminal defense attorneys face in obtaining access to the field or evidence from state authorities. ${ }^{102}$ Because the defense is not an official organ of the court, it cannot benefit from established channels of mutual cooperation in criminal matters. ${ }^{103}$ More generally, international organizations, non-governmental organizations, and domestic authorities have not been as accommodating of defense requests for evidence as they have been of prosecution requests. ${ }^{104}$ While the "prosecutor is assumed to have the power and support of the state community" in enforcing international criminal law, the defense is seen as an outsider or

\footnotetext{
${ }^{96}$ Hooper (n 72) 13-17; Keïta (n 95) 7-8.

${ }_{97}$ See Hooper (n 72) 13-17; Keïta (n 95) 7.

${ }^{98}$ Khan and Shah (n 13) 225.

99 ibid 226.

100 ibid.

101 See, eg, Institute for War \& Peace Reporting, ICC Kenya Probe 'Hampered by Intimidation,' 12 January

2012, <https://iwpr.net/global-voices/icc-kenya-probe-hampered-intimidation> accessed 4 November 2016.

102 Caroline Buisman, 'The Prosecutor's Obligation to Investigate Incriminating and

Exonerating Circumstances Equally: Illusion or Reality?’ 27 Leiden J Intl L 205, 212-15; Jacob Katz Cogan, 'International Criminal Courts and Fair Trials: Difficulties and Prospects,' (2002) 27 Yale J Intl L 111, 131; Fauveau-Ivanovic (n 12) 2, 12; Maria Igorevna Fedorova, The Principle of Equality of Arms in International Criminal Proceedings (Volume 55, School of Human Rights Research Series 2012) 190, 205-09 ; Jalloh \& DiBella (n 67) 264; Michael A. Newton, 'Evolving Equality: The Development of the International Defense Bar' (2011) 47 Stanford J Intl L 379, 388-90.

103 IBA, Fairness at the ICC (n 68) 32.

104 See Respondent \# 7 ("Lack of security, distance, lack of government cooperation make defence investigations and presentation of defence case extremely problematic, much more than at any other court"); Newton (n 102) 390 (noting that national authorities 'have established detailed mechanisms for providing that information to the prosecution teams, but have often been far less forthcoming to defense investigators').
} 
even a pariah. ${ }^{105}$ The underfunding of defense investigations exacerbates these structural barriers to defense investigations.

Survey responses, as well as the court's own records, suggest that to the extent that resources for the defense are limited, this is largely the result of administrative, rather than judicial decisions. The Registry is under pressure from states parties to keep the legal aid budget under control, ${ }^{106}$ so it has taken decisions that, in defense attorneys' views, have at times interfered with the defense's ability to effectively prepare cases. Judges have often supported the defense in its efforts to maintain the staff and resources necessary for adequate representation of defendants throughout the proceedings. ${ }^{107}$ This may explain why survey comments about the inadequacy of investigative resources focused on the Registry and States Parties, rather than on Chambers.

\section{Prosecutorial Disclosure}

Recognizing the investigative challenges that the defense faces in international criminal cases, the drafters of the Rome Statute charged the prosecution with investigating objectively. ${ }^{108}$ Prosecutors are supposed to seek out "incriminating and exonerating circumstances equally" "in order to establish the truth." 109 This feature of ICC procedure is influenced by the inquisitorial model, under which prosecutors (or, in some countries, investigative judges) are seen as neutral officials charged with investigating all evidence objectively in the interests of justice. In that model, the defense has traditionally assumed a more passive role at the investigative stage and has focused primarily on reviewing evidence gathered by the prosecution. ${ }^{110}$

Yet defense attorneys have expressed skepticism that the ICC prosecutor is in a good position to investigate on the defense's behalf. ${ }^{111}$ As Caroline Buisman, an ICC scholar and defense counsel, writes, "it is perhaps over-idealistic to expect a prosecutor to search purposefully for information that is contrary to his or her perception of the facts and his or her case." 112 Moreover, since "the Prosecutor does not, as a rule, question the accused or otherwise have his or her account of events, it is questionable whether she can have a

\footnotetext{
105 Fedorova (n 102) 227, 444.

106 Review of ICC Legal Aid System (n 72) 1.

107 International Bar Association, Counsel Matters at the International Criminal Court (2012) 25; see also supra text and accompanying notes 80-84.

108 Rome Statute (n 16) art 54(1)(a) ("In order to establish the truth, extend the investigation to cover all facts and evidence relevant to an assessment of whether there is criminal responsibility under this Statute, and, in doing so, investigate incriminating and exonerating circumstances equally."); see also Jalloh \& DiBella (n 67) 277; Fedorova (n 102) 445-46.

109 Rome Statute (n 16) art 54(1)(a).

110 See, eg, Sonja B Starr, 'Ensuring Defense Counsel Competence at International Criminal Tribunals,' (2009) 14 UCLA J. Intl L \& Foreign Affairs 169, 184-85; Jenia I Turner, 'Plea Bargaining and Disclosure in Germany and the United States: Comparative Lessons,' (2016) 57 William \& Mary L Rev 1549, 1559.

111 Buisman (n 102); see also Hooper (n 72) 13; Respondent \# 15 (“[La CPI] pretend confier au Procureur le soin de travailler a decharge ce qu'il s'abstient bien .... Soit on donne les moyens a la defense de faire un vrai travail de contre-enquete (en l'absence de juge d'instruction et de police, cela serait logique), soit on se retrouve dans une situation inequitable vis a vis de la defense (ce qui est le cas)).

112 Buisman (n 102) 224.
} 
realistic basis for such an enquiry." 113 Indeed, studies of investigations in inquisitorial systems and at the ICC have found that state authorities are not adequately investigating exculpatory evidence. $^{114}$

ICC prosecutors are further required to disclose promptly to the defense any exculpatory evidence that they have in their possession. Chambers have held that prosecutors must disclose "the bulk" and in some cases, "the totality" of exculpatory evidence before the confirmation of charges hearing. ${ }^{115}$ In any event, all exculpatory evidence must be disclosed "as soon as practicable." 116

The ICC has affirmed that disclosure of exculpatory evidence and evidence material to the defense is critical to ensuring a fair trial. ${ }^{117}$ The proceedings against Thomas Lubanga were twice stayed to remedy disclosure failures by the prosecution. ${ }^{18}$ The Lubanga Trial Chamber concluded that it could not ensure a fair trial until the evidence was disclosed at least to the court for evaluation of its exculpatory nature. ${ }^{119}$

Because disclosure is so central to ensuring a procedural balance between the parties, it has been the subject of multiple disputes at the court. ${ }^{120}$ Not surprisingly, survey responses highlighted disclosure as the area of greatest discontent. Almost two-thirds of respondents stated that the court has unduly limited their ability to review disclosed evidence. In response to a subsequent question, $62.5 \%$ of respondents stated that the court had not demanded adequate disclosure from the prosecution, while another $18.75 \%$ thought that the court had only "sometimes" demanded adequate disclosure.

Several different concerns about disclosure emerged from the open-ended responses. First, respondents opined that the court did not do enough to ensure that the prosecution disclosed evidence in a timely fashion. They complained of "late disclosure" and the "need to file numerous if not endless disclosure requests." ${ }^{121}$ In the same vein, a respondent reported that " $\mathrm{t}]$ he OTP served thousands of pages of evidence 14 days before the Preliminary Hearing as an attempt to prevent the Defence from conducting full analysis of their case." "The same respondent noted that "[t]he Court permitted a timetable favourable

\footnotetext{
113 ibid 224.

114 ibid 211-219; Jacqueline Hodgson, 'The Role of the Criminal Defence Lawyer in an Inquisitorial Procedure: Legal and Ethical Constraints,' (2006) 9 Legal Ethics 125, 135-36, 136 n 48.

115 Prosecutor v. Lubanga, Decision on the Final System of Disclosure and the Establishment of a Time Table, ICC-01/04-01/06-102, Pre-Trial Chamber I, 15 May 2006 9ף[124]-[133].

116 Prosecutor $v$. Ruto et al, Decision Setting the Regime for Evidence Disclosure and Other Related Matters, ICC01/09-01/11-44, Pre-Trial Chamber II (06 April 2011) $\mid[6]$.

117 Prosecutor v. Ongwen, Appeals Chamber (Judgment on the appeal of the Prosecutor against the decision of Pre-Trial Chamber II entitled "Decision Setting the Regime for Evidence Disclosure and Other Related Matters"), Appeals Chamber, ICC-02/04-01/15-251 (17 June 2015) I [40] ("The Appeals Chamber has previously held that "the disclosure process is essential in ensuring the fairness of the proceedings and that the rights of the defence are respected, in particular the principle of equality of arms"'”) (citations omitted). 118 Joyce Aluoch, 'Ten Years of Trial Proceedings at the International Criminal Court,' (2013) 12 Wash U Global Stud L Rev 433, 441.

119 Prosecutor v. Lubanga, Trial Chamber (Decision on the Release of Thomas Lubanga Dyilo), ICC-01/04-01/06 (July 2, 2008) [ब 30].

120 Whiting, 'Dynamic Investigative Practice' (n 45) 166; Khan \& Buisman (n 12) 1029.

121 Respondent \# 6; see also Respondent \# 10 ("Perhaps disclosure of the trial material should take place sooner - at present, e.g. in [, the trial witnesses were largely different to the Confirmation witnesses.").

122 Respondent \# 21.
} 
to the OTP. The date of possession of the evidence showed it could have been served sooner." $" 123$

Respondents further complained that the court did not consistently sanction prosecutors for disclosure violations. ${ }^{124}$ Khan and Buisman have expressed similar concerns in their public writings - that prosecutors frequently disclose additional evidence after the deadlines imposed by Chambers and that Chambers tend to excuse the delay. ${ }^{125}$ Another disclosure-related problem identified by survey respondents was that it is difficult to "get the Court to request states to disclose material" - a complaint that echoes those made by attorneys at the ad hoc tribunals. ${ }^{126}$

Particularly because it is combined with insufficient staffing and investigation resources for the defense, late disclosure has reportedly frustrated defense efforts to prepare adequately for confirmation hearings and trials. ${ }^{127}$ One respondent explained that his or her defense team was able to review the disclosed evidence adequately only because the Chambers delayed first the confirmation hearing and then the trial proceedings. ${ }^{128}$ This criticism echoes a complaint by defense attorneys at the ICTY: that by stretching out disclosure of evidence over time, the prosecution "puts the defence off-balance and makes it impossible to "develop and stick to a proper defence plan." 129 Independent observers of the court concur that "the disclosure process is often rife with delays and the subject of considerable and time-consuming litigation, which can further prolong the proceedings." 130

Another concern of respondents was that the court authorized disproportionate and unnecessary redactions of disclosed documents. At the ICC, the prosecution can seek permission to redact information that would identify witnesses, their families, or others who might be placed at risk on account of the court's work. ${ }^{131}$ Disclosure may also be restricted to protect the integrity of ongoing investigations, national security information, or confidentiality agreements authorized under the Statute. ${ }^{132}$ While redactions and summaries

\footnotetext{
123 Respondent \# 21.

124 Respondent \# 23 ("The court most of the time accommodates the Prosecutor's unreasonable disclosure violations. The Prosecutor has hardly ever been sanctioned except in very limited cases for its disclosure violations."); Respondent \# 14 ("The duty to disclose exculpatory evidence is not as robustly enforced and it is usually up to the defence to demonstrate the need.");

125 Khan and Buisman (n 12) 1033-34.

126 Respondent \# 10; cf Newton (n 102) 388-90, 417-27.

127 See, e.g., Respondent \# 19 (“did not provide us with necessary software to read prosecution evidence and failed to oblige the prosecution to present evidence in a different more accessible format"); Respondent \# 21 ("The OTP served thousands of pages of evidence 14 days before the Preliminary Hearing as an attempt to prevent the Defence from conducting full analysis of their case."); see also Respondent \# 14 (“'The proceedings are victim oriented and Defence Counsel are not afforded enough time to conduct their own investigations and adequately review prosecution disclosures.").

128 Respondent \#10.

${ }^{129}$ Jarinde Temminck Tuinstra, 'Defending the Defenders: The Role of Defence Counsel in International Criminal Trials' (2010) 8 J Intl Crim Just 463, 479 (quoting Stephane Bourgon, 'Procedural Problems Hindering Expeditious and Fair Justice' (2004) 2 J Intl Crim Just 526, 529).

130 Expert Initiative (n 4) 103.

131 Rome Statute (n 69) art 68(5); ICC RPE (n 41) rr 81(3),(4).

132 ICC RPE (n 41) rr 81(2)-(4), 82.
} 
of witness statements are permitted before confirmation to address such concerns, witness identities must ultimately be disclosed before trial. ${ }^{133}$

Defense attorneys believed that judges were overly deferential to the prosecution in authorizing redactions. As one respondent explained:

Witness protective measures have a deleterious effect on disclosure - the Court inevitably? [sic] accepts what the prosecutor tells it as to the risks to its witnesses when in fact there is little or no risk at all. The Court is also unduly protective of intermediaries and of the sums provided to witnesses and intermediaries. There should be fuller disclosure of that.

In public comments, too, some defense attorneys have criticized the redactions process as "reflexive," "unwieldy[,] and unmanageable."134

Outside observers have likewise noted that the redactions process is time-consuming and unpredictable. Chambers have adopted different approaches to authorizing initial redactions and lifting redactions later in the process. ${ }^{135}$ As a result, "[t]he same evidence may be disclosed to the Defence multiple times with different degrees of redactions. Effectively, the Defence may be required to review the same material three times before the actual identity of the witness or other key information may be disclosed to the Defence and allows for full Defence investigations to take place at a very late stage in proceedings." 136 This process heavily taxes the already thinly stretched staffing resources of the defense.

Survey responses were not conclusive as to the reason for the judges' perceived failure to ensure prompt and comprehensive disclosure. No respondents suggested that the problem resulted from an excessive focus on efficiency. Instead, some opined that judges gave undue deference to prosecutorial claims of exigency, whether in terms of the timing of disclosure or in terms of the necessary redactions. ${ }^{137}$ Academic commentary is divided on this question. Whiting has argued that disclosure delays are the inevitable product of prosecuting complex international crimes involving mountains of documentary evidence and multitudes of vulnerable witnesses needing protection. ${ }^{138}$ Others have claimed that delays are fueled by inconsistent judicial approaches to disclosure. ${ }^{139}$ What is clear is that neither

133 ICC RPE (n 41) r 81(5).

134 Khan and Shah (n 13) 208; see also ibid 209 ("The above-mentioned reflexive, if not cavalier, attitude toward redactions by the ICC prosecution, and the wide scope and imposition of redactions at the ICCbeyond merely witnesses and their families - has resulted in a bureaucratic, overbroad, and resource-draining redaction regime. At its worst, such a regime risks resulting in a fundamental miscarriage of justice, and otherwise greatly hinders the work of the defense.").

135 Expert Initiative (n 4) 113-115.

136 ibid 115.

137 One respondent connected the disclosure problems to the ICC's "victim oriented" proceedings. Respondent \# 14. Another noted that "the court accepts what the prosecutor tells it as to the risks to its witnesses when in fact there is little or no risk at all." Respondent \# 10.

138 Whiting, 'Dynamic Investigative Practice' (n 45) 179-82.

139 Expert Initiative (n 4) 103 ("Disputes as to the scope, adequacy, and timing of disclosure are frequent, and can be exacerbated by ambiguities in the law and a lack of clarity and predictability in the Court's practice."); see also IBA, Fairness at the International Court (n 68) 24 ("The prosecution has repeatedly sought an AC decision to clarify the disparate approaches to disclosure to prevent continued uncertainty and to facilitate more effective use of its resources in preparation for the confirmation hearing. However, leave to appeal has been consistently refused.”). 
defense attorneys nor outside observers believe that the source of the disclosure problems is managerial judging. In fact, managerial judging is seen as a possible remedy for late and incomplete disclosure. ${ }^{140}$

\section{Confirmation of Charges}

The survey did not directly ask defense attorneys to comment on the confirmation of charges process, but several respondents nonetheless raised the issue when asked about top procedural reforms they would like to see implemented at the ICC. The confirmation of charges is an adversarial proceeding on the basis of which the Pre-Trial Chamber decides whether "substantial grounds" exist to believe that the person committed the crimes charged. The hearing is supposed to protect "against wrongful prosecution and ensur[e] judicial economy by allowing to distinguish between cases that should go to trial from those that should not." 141 Although the process is supposed to safeguard against unwarranted accusations, several defense attorneys criticized it as unfair and inefficient, at least as practiced at present. Views on how the confirmation process should be reformed differed widely among defense attorneys, however, just as they do among other observers of the court.

Some attorneys argued that the confirmation process should be strengthened and that judges should be more rigorous in sifting out unwarranted charges. ${ }^{142}$ As one respondent explained:

The threshold for the confirmation of charges is so low. This allows charges which should have been filtered and dismissed to be confirmed for trial. Due to the reluctance of Pre-trial Judges to grant leave for appeal of most confirmation decisions, the cases are sent for trial on very deficient and defective charges. The ICC Judges should be more active and rigorous during the confirmation process and during trial. ${ }^{143}$

Another respondent lamented the variable and unpredictable approaches to confirmation by different judges. ${ }^{144} \mathrm{He}$ or she also criticized judges for refashioning charges

\footnotetext{
140 See, eg, WCRO Expediting Proceedings Report (n 4) 61 ("Late disclosure of material by the Prosecution to the Defense has been one of the principal causes of delay at the ICC."); Whiting, 'Disclosure Challenges at the ICC' (n 42) 1007 (“Commentators echo the complaints of the defense and judges, deplore the prosecution's repeated failures to meet its disclosure obligations, and urge reforms.”).

${ }^{141}$ Prosecutor v. Bemba (Decision Pursuant to Article 61 (7)(a) and (b) of the Rome Statute on the Charges of the Prosecutor Against Jean-Pierre Bemba Gombo), Pre-Trial Chamber II, , ICC-01/05-01/08-424 (15 June 2009); Triestino Mariniello, 'Questioning the Standard of Proof: The Purpose of the ICC Confirmation of Charges Procedure' (2015) 13 J Intl Crim Just 579, 583; Nerlich, 'The Confirmation of Charges Procedure at the International Criminal Court: Advance or Failure?' (2012) $10 \mathrm{~J}$ Intl Crim Just 1339, 1354 (noting that the confirmation of charges hearing was designed at least in part to serve as a check on the prosecutor and to filter out cases in which charges are not sufficiently supported by the evidence).

142 See, eg, Respondent \# 21 (proposing greater judicial control over the Prosecutor as a needed procedural reform); Respondent \# 23 (arguing that ICC should "streamline the Pre-trial proceedings and raise the threshold bar for confirmation of charges.")

143 Respondent \# 23.

144 Respondent \# 16 ("At this time, charging instruments vary from case to case and this provides insufficient notice of charges to the defendants which is in violation of rights.").
} 
at trial through Regulation 55, which allows trial judges to recharacterize the charges confirmed by pre-trial judges. ${ }^{145}$ The respondent opined that this practice renders the confirmation process meaningless and leaves defendants without adequate notice about the charges they face. ${ }^{146}$

While some respondents argued for a higher standard of proof at confirmation, others thought that the confirmation of charges procedure should be abolished altogether. ${ }^{147}$ One person suggested that introducing an investigative judge into the ICC system would offer the best solution to some of the investigative and confirmation difficulties:

[The top three procedural reforms:] abolish the confirmation hearing; abolish the bifurcated (even tri-furcated) trials; creation of an investigative judge. I have long been in favour of the adversarial model for ICL, but the problems with investigations at the ICC are huge, witnesses are bribed, influenced from practically all sides. I am not confident the parties can address this and at trial it is too late (cp. Kenya case). An investigative judge, in some form, can bring in the deeply needed supervision of the investigations. ${ }^{148}$

Another respondent suggested that involving the defense earlier in the process would help the accused prepare to dispute unsubstantiated charges more effectively. This respondent believed that if ad hoc counsel were assigned as soon as a new situation is opened, counsel could "build up the nucleus of the Defence... case. If then a Case opens in a Situation, the ad hoc counsel will have to hand over their case files to the newly appointed counsel for the defence...." ${ }^{149}$ As the respondent elaborated, such early appointment could help secure equality of arms:

The key disadvantage between OTP and Defence is up to now, that OTP has a continuity in working on a case for years before a case started. Defence Counsel started normally at 'zero' at the beginning of a case. Assignment of ad hoc counsel and handing over of files under a fixed protocol could balance these structural differences. ${ }^{150}$

\footnotetext{
145 Regulations of the Court ( $\mathrm{n}$ 40) reg 55 (providing that in its final judgment, the "Chamber may change the legal characterization of facts to accord with the crimes [...] or to accord with the form of participation of the accused $[\ldots]$ without exceeding the facts and circumstances described in the charges and any amendments to the charges.").

146 Respondent \# 16 ("In addition, the proliferation of the use of Regulation 55 to notice additional modes of liability and other charges even prior to trial has rendered the process of $\mathrm{CoC}$ nearly meaningless (i.e. modes of liability litigated and not found as 'charged' modes of liability in the $\mathrm{CoC}$ process are later noticed via Regulation 55”).

147 Respondent \# 18 (stating that the "confirmation hearing can be abolished, serves absolutely no purpose").

148 Respondent \# 18.

149 Respondent \# 22. This view has been expressed by some defense attorneys in public comments as well. See J. Dieckmann \& C. Kerll, 'Representing the "General Interests of the Defence": Boon or Bane? - A Stocktaking of the System of ad hoc Counsel at the ICC', Intl Crim L Rev 11 (2011) 105, 134-35.

150 Respondent \# 22. The same respondent also argued that defense teams should be larger during the pre-trial stage- the Registry should appoint two, rather than just one counsel before confirmation. This would help even the field between the prosecution and the defense and ensure a fair trial. ibid. The OPCD could theoretically fulfill these tasks of preparing the case for the defense before the first appearance of the accused. But because the OPCD's staff is so small, in practice, it does not have the capacity to do so.
} 
Outside commentators echo defense attorneys' concerns about the inefficiency and unpredictability of the confirmation process. Although the confirmation process was originally envisaged by some as a means of expediting proceedings, ${ }^{151}$ it is now widely believed to have extended and encumbered trial preparation. ${ }^{152}$ It has taken the court on average almost one year to reach a confirmation decision after the initial appearance of the accused. ${ }^{153}$ Likewise, trials have begun, on average, more than a year and a half after a confirmation decision has been handed down, suggesting that the pre-confirmation process has not effectively narrowed the issues and expedited the proceedings. ${ }^{154} \mathrm{~A}$ number of commentators have concluded that the confirmation process is too costly and timeconsuming, ${ }^{155}$ and some have called for its abolition. ${ }^{156}$

The other concern expressed by respondents-about inconsistent approaches to confirmation - is also widely shared. Scholars have commented on the disagreements among judges about the purpose of the confirmation hearing, the standard of proof, the timing and scope of pre-confirmation disclosure, and the division of responsibilities between Pre-Trial and Trial Chambers. ${ }^{157}$

\footnotetext{
${ }^{151}$ See, eg, Prosecutor v. Bemba (Decision on the Evidence Disclosure System and Setting a Timetable for Disclosure Between the Parties), Pre-Trial Chamber III, ICC-01/05-01/08-55 (31 July 2008) [15], [19]; Gilbert Bitti, 'Two Bones of Contention Between Civil Law and Common Law: The Record of Proceedings and the Treatment of a Concursus Delictorum' in Horst Fischer, Claus Kress, and Sascha Rolf Lüder (eds), International and National Prosecution of Crimes Under International Law: Current Developments (Berlin Verlag 2001) 277; Kai

Ambos and Dennis Miller, 'Structure and Function of the Confirmation Procedure Before the ICC from a Comparative Perspective' (2007) 7 Intl Crim L Rev 335, 348.

152 See, eg, Friman (n 4) 921, 930; Nerlich (n 141) 1354; Expert Initiative (n 4) 93-95; WCRO Confirmation of Charges Report (n 44) 85-86.

153 See, eg, Ignaz Stegmiller, 'Confirmation of Charges, in The Law and Practice of the International Criminal Court' in Carsten Stahn (ed), The Law and Practice of the International Criminal Court (OUP 2015) 905; Expert Initiative (n 4) at 93.

154 Stegmiller (n 153) 905-06; Expert Initiative (n 4) 93. For an analysis of the reasons why confirmation hearings have not entirely fulfilled their purpose in this respect, see Expert Initiative (n 4) 83-84; WCRO Confirmation of Charges Report ( $\mathrm{n} 44$ ) 85-86. On the other hand, it is worth noting that at the ICTY, as of 2009, the pre-trial stage (from the date the defendant comes into the tribunal's custody to the date of the opening trial arguments or of the first plea hearing) lasted on average 1.9 years, and at the ICTR-3.6 years. Jean Galbraith, 'The Pace of International Criminal Justice,' (2009) 31 Mich J Intl L 79, 117. A study conducted in 2011 found that the median length of the pretrial phase (measured as the number of days between the initial appearance and either (1) the first day of trial, (2) the date a plea was entered, or (3) the date that some other conclusion of the pretrial period was reached) was eighteen months. See Maximo Langer and Joseph W. Doherty, 'Managerial Judging Goes International but its Promise Remains Unfulfilled: An Empirical Assessment of the ICTY Reforms' (2011) 36 Yale J Intl L 241, 252. The ICC pretrial process therefore appears to be slower than that of the ICTY, but faster than the process at the ICTR.

155 Nerlich (n 141) 1354; Stegmiller (n 153) 906.

${ }^{156}$ Christoph Safferling, International Criminal Procedure (OUP 2012) 343; Schabas, International Criminal Court: A Commentary on the Rome Statute 735 (OUP 2010); Expert Initiative (n 4) 93-95, 100.

157 See, eg, Mariniello (n 141) 580. For example, some Pre-Trial Chambers have required the prosecution to be "trial ready" at confirmation and have demanded a relatively high standard of proof to confirm charges. See, eg, Prosecutor v. Mbarushimana (Judgment on the appeal of the Prosecutor against the decision of Pre-Trial Chamber I of 16 December 2011 entitled "Decision on the confirmation of charges"), Appeals Chamber, ICC-01/0401/10 OA4 (30 May 2012), [44]; see also Prosecutor v. Muthaura \& Kenyatta (Decision Requesting Observations on the "Prosecution's Request to Amend the Final Updated Document Containing the Charges Pursuant to Article 61(9) of the Statute,"), ICC-01/09-02/11 (29 January 2013) [9]; Prosecutor v. Gbagbo (Decision adjourning the hearing on the confirmation of charges pursuant to article 61(7)(c)(i) of the Rome Statute), ICC-02/1101/11 (3 June 2013) [25]; Prosecutor v. Lubanga (Decision on the Confirmation of Charges), Pre-Trial Chamber,
} 
While there is broad consensus that Chambers employ inconsistent standards at confirmation and that the process is too lengthy, defense attorneys and other commentators tend to disagree on the question whether judges have been sufficiently rigorous in filtering out charges. Whereas defense attorneys believe that judges are not sufficiently rigorous, other observers have concluded that the Pre-Trial Chambers have generally succeeded in disposing of unsupported charges at confirmation. ${ }^{158}$ In support of the latter view, commentators point out that as of May 2014, Chambers had confirmed charges against twelve suspects and declined to confirm charges against four suspects. ${ }^{159}$ In two of the twelve cases in which charges were ultimately confirmed, the Prosecutor had to reconsider the initial charges filed or conduct further investigations, after judges suggested that they would not confirm the charges as originally filed. ${ }^{160}$ Furthermore, Pre-Trial Chambers have reduced the temporal and territorial scope of charges in a number of cases. ${ }^{161}$

Observers have offered diverging interpretations of these figures. Some have argued that the $25 \%$ declination rate reflects judges' rigorous review of the evidence and is a mark of success. ${ }^{162}$ Yet others, including some survey respondents, have focused instead on the court's failure to dispose of other arguably unmeritorious cases at confirmation ${ }^{163}$ - the Ngudjolo case, which resulted in an acquittal; the cases against Ruto and Sang, which were terminated by the Trial Chamber for insufficient evidence; ${ }^{164}$ and the cases against Kenyatta and Muthaura, which were ultimately withdrawn by the Prosecutor for lack of evidence. ${ }^{165}$ These observers believe that the court should be even stricter in its review of prosecutorial charging decisions.

How one interprets these figures depends on one's view of the Kenyan cases, which represent four of the five cases where charges were terminated or withdrawn after confirmation. The Prosecutor has claimed that bribery and intimidation led witnesses in these cases to recant or refuse cooperating with the prosecution, which resulted in the ultimate termination or withdrawal of charges. ${ }^{166}$ By contrast, a number of defense attorneys believe that the prosecution failed to investigate and present to the court credible evidence that the defendants were responsible for the crimes charged. In the end, whether or not one agrees with defense views on the effectiveness of the filtering mechanism at confirmation, it

ICC-01/04-01/06-803 (29 January 2007) [37]-[39] (requiring "compelling" evidence and "concrete and tangible proof"); Mariniello (n 141) 595-96; Stegmiller (n 153) 897 (arguing that "the wording of 'concrete and tangible proof suggests that the test is rather high"). Others have been less demanding and have held that once the "substantial grounds to believe" threshold is met, the credibility of the evidence is to be determined at trial. Mariniello (n 141) 589.

${ }^{158}$ Expert Initiative (n 4) 81; Nerlich (n 141) 1347-48.

${ }^{159}$ Expert Initiative (n 4) 80.

160 ibid 80-81.

161 ibid 88 .

162 ibid 85.

${ }^{163}$ See, eg, Respondent \# 23; see also Expert Initiative (n 4) 85.

164 Prosecutor v. Ruto \& Sang (Public Redacted Version of: Decision on Defence Applications for Judgments of Acquittal), Trial Chamber V(A), ICC-01/09-01/11 (5 April 2016) ๆ [131] (reasons of Judge Fremr); ๆ [135] (reasons of Judge Eboe-Osuji).

165 Prosecutor v. Kenyatta, Notice of withdrawal of the charges against Uhuru Muigai Kenyatta, Office of the Prosecutor, ICC-01/09-02/11-983 (5 December 2014); Khan \& Shah (n 12) 218-19; Respondent \# 10.

166 See, eg, Ruto \& Sang 9ף [140]-[150] (reasons of Judge Eboe-Osuji) (noting that witness interference "impede[s] a neutral appreciation" of the prosecution's case). 
is important to take them into account as the court considers whether and how to restructure this key stage of the proceedings.

\section{Interlocutory Appeals}

Another procedure that defense attorneys identified as needing reform concerns interlocutory appeals. Article 82(1)(d) of the Rome Statute provides that a party may appeal a "decision that involves an issue that would significantly affect the fair and expeditious conduct of the proceedings or the outcome of the trial, and for which, in the opinion of the Pre-Trial or Trial Chamber, an immediate resolution by the Appeals Chamber may materially advance the proceedings." ${ }^{~} 167$ In order to file an interlocutory appeal, a party must first obtain permission from the Pre-Trial or Trial Chamber that issued the impugned decision.

Overall, respondents expressed dissatisfaction with the way the interlocutory appeal mechanism has operated at the ICC. A majority opined that Pre-Trial and Trial Chambers grant leave to file an interlocutory appeal too sparingly. As one attorney complained:

The ICC procedure requires leave to appeal to be granted before an interlocutory appeal can be filed. All applications for leave to appeal were rejected. It did not matter whether the leave sought related to a fundamental fair trial violation as right of notice or significant defects in the form of the indictment. $^{168}$

Several respondents therefore suggested reforms to the interlocutory appeal process. One suggested that parties should not need to request permission to appeal confirmation decisions. ${ }^{169}$ Others thought that the Appeals Chamber should decide whether to grant leave to appeal on interlocutory matters. ${ }^{170}$ More broadly, respondents thought the court should grant authorization to appeal preliminary matters more frequently. ${ }^{171}$

A quick review of defense motions for leave to appeal shows that judges are in fact quite parsimonious when it comes to permitting interlocutory appeals. Out of 458 issues on which the defense sought leave to appeal, Chambers granted leave for only 51 issues, yielding an average grant rate of $11.13 \% .{ }^{172}$ By contrast, Chambers granted leave to the prosecution's request much more frequently. Out of 90 issues for which the prosecution requested leave to appeal, Chambers granted leave on 34 issues, yielding an average grant

\footnotetext{
${ }^{167}$ Rome Statute (n 69) art 82(1)(d).

168 Respondent \# 23; see also Respondent \# 18 ("I think the leave to appeal, if necessary at all, should be decided by the A Ch. denying leave by the same TC or PTC will be easily experienced as unduly limiting appeal"); Respondent \# 21 ("The Defence filed for leave to appeal against the Preliminary Hearing Decision and the Judge who had decided the issue also decided the leave to appeal which she rejected.”).

${ }^{169}$ Respondent \# 14.

170 Respondents \#\# 18, 21.

171 Respondents \#\# 7, 18, 23.

172 The grant rate differed widely from cases to case, so the experience of individual defense attorneys is likely to differ as well. For example, in Lubanga, the defense sought leave to appeal a total of 55 issues, but judges granted the leave to appeal as to only 15 issues (yielding a grant rate of 27\%). In Prosecutor $v$. Gaddafi and AlSenussi, the Pre-Trial Chamber granted leave to appeal on only one out of seven issues raised by the defense (yielding a grant rate of $14 \%$, closer to the average).
} 
rate of $37.78 \% .{ }^{173}$ The prosecution therefore succeeds in reaching the Appeals Chamber for interlocutory appeals almost three and half times more often than does the defense.

One cannot tell, simply based on these figures, whether the requests for leave to appeal by the prosecution and by the defense are equally meritorious. The defense filed almost 2.5 times more requests for interlocutory appeals than the prosecution; in those requests, defense attorneys raised on average 5 times more issues than did prosecutors. ${ }^{174} \mathrm{It}$ is therefore possible that a greater percentage of defense motions failed to meet the criteria for interlocutory appeals.

On the other hand, precisely because the defense tends to file more motions for interlocutory appeals, to the extent that the regime is not functioning properly, it affects the defense more frequently than the prosecution. Furthermore, a number of the issues on which leave to appeal is denied, such as the confirmation of charges or the recharacterization of charges, affect the accused directly and significantly. ${ }^{175}$ Defense attorneys' concern about the low rate of success of requests for interlocutory appeal is therefore understandable.

Because Chambers grant leave for interlocutory appeals so rarely, a number of inconsistent decisions by Pre-Trial and Trial Chambers remain in place, reducing the predictability of ICC procedures. For that reason, it is not only defense attorneys, but also outside observers who have argued that leave to appeal should be granted more generously and that a separate chamber responsible for granting leave to appeal should be created. ${ }^{176}$

Respondents did not speculate what might drive the frequent rejections of requests for interlocutory appeals. Judges may not like having their procedural decisions reviewed on appeal, or they may simply believe that the defense is not raising meritorious issues. Judges may also be concerned that interlocutory appeals take up too much time. Scholars studying the ad hoc tribunals have argued that judges restricted interlocutory appeals there as a means

\footnotetext{
173 Again, as with defense requests, the success of prosecution requests varies significantly from case to case. In Lubanga, Chambers granted $62.5 \%$ of the prosecution's requests for leave to appeal.

174 The defense filed 133 requests to file interlocutory appeal, while the prosecution filed 55 requests.

175 Stegmiller (n 153) 895 (noting that leave to appeal was denied with respect to all confirmation decisions, except in Mbarushimana, where the prosecution was granted leave to appeal the declination of charges); Prosecutor $v$. Bemba (Public Redacted Version of "Decision on 'Defence Request for Leave to Appeal the Decision on the Temporary Suspension of the Proceedings Pursuant to Regulation 55(2) of the Regulations of the Court and Related Procedural Deadlines"' of 11 January 2013), Trial Chamber III, CC-01/05-01/08-2487-Red (16 January 2013) [33], [35]-[36] (denying defense request to appeal the recharacterization of charges).

176 WCRO Expediting Proceedings Report (n 4) 52 (citing Christopher Staker, 'Article 82: Appeal against decision of acquittal or conviction or against sentence' in Otto Triffterer (ed), Commentary on the Rome Statute of the International Criminal Court: Observers' Notes, Article by Article (Nomos 1999) 1029, 1031; Expert Initiative (n 4) 163 ("It would therefore seem to be a wise course of action to establish a mechanism whereby issues of a sensitive (procedural or substantive) nature that are arguably affecting a trial decision should be capable of interlocutory appeal where a failure to address that matter at an early stage could negatively affect the position of a party, the fairness of proceedings or their integrity."); see also ibid 164 ("[The separate Trial Chamber] could be composed of the Presiding Judges of the Trial Chambers, which would have the benefit of ensuring consistency of approach between Trial Chambers. It would also ensure that one member of the Trial Chamber that rendered the impugned decision would participate so as to ensure that full consideration be given to both the effect of a possible appeal on trial proceedings and the effect of resolving the matter thereupon.").
} 
of expediting proceedings. ${ }^{177}$ This may therefore be one area in which ICC judges, too, are limiting defense representation to promote efficiency. ${ }^{178}$

\section{Victim Participation}

Defense attorneys also expressed concerns about victim participation in ICC proceedings. In a departure from its predecessor international criminal courts, the ICC allows extensive victim participation at pretrial and trial. This novel procedural framework reflects a reorientation away from a purely retributive model of justice toward a more restorative one. ${ }^{179}$

Acting through legal representatives, victims can take part at both pre-trial and trial, although most modes of participation require judicial permission. Victims can attend confirmation hearings and have been permitted to express their views and concerns at the hearing through their legal representative. ${ }^{180}$ Victims' legal representatives have also been allowed to question defense witnesses at confirmation hearings, as long as victims' personal interests would be affected by the testimony. ${ }^{181}$ At trial, victims have been permitted to make oral and written submissions, question witnesses, present and challenge evidence, and be heard as witnesses. ${ }^{182}$ If the accused is convicted, victims can also take part in the reparations proceedings. ${ }^{183}$

In part because the crimes adjudicated by the ICC have so many victims, the process of determining who qualifies as a victim participant has proven difficult, lengthy, and costly. ${ }^{184}$ Victim applications must be reviewed by the Registry, Chambers, and the parties, and identifying information must often be redacted. ${ }^{185}$ The process of redacting and reviewing the applications has consumed extensive resources.

\footnotetext{
177 See, eg, Langer (n 6) 901 ("Finally, two additional reforms that also have gone in the direction of the managerial judging system are the elimination of a distinction between the guilt-determination and sentencing phases and the limitation of interlocutory appeals."); Langer \& Doherty (n 6) 250 (noting that UN experts and ICTY judges attempted to narrow the availability of interlocutory appeals at the ICTY "on the theory that fewer interlocutory appeals would mean shorter pretrial and trial proceedings").

178 As some have argued, however, the limitation on interlocutory appeals may not be a particularly efficient managerial technique. In many cases, interlocutory appeals may advance efficiency over the long term, as they clarify the law and reduce disputes between the parties on certain issues. Moreover, in some cases, an interlocutory appeal may be less costly than a post-conviction appeal, particularly where the issue appealed significantly affected the fairness of the proceeding and the remedy after conviction is likely to be much more costly than a correction before or during trial.

${ }^{179}$ Sergey Vasiliev, 'Victim Participation Revisited-What the ICC Is Learning About Itself in Carsten Stahn (ed), The Law and Practice of the International Criminal Court (OUP 2015) 1133, 1134-36.

${ }^{180}$ Christine Van den Wyngaert, 'Victims Before International Criminal Courts: Some Views and Concerns of an ICC Trial Judge' (2011) 44 Case Western Reserve J Intl L 475, 485.

181 Van den Wyngaert (n 180) 485.

182 Van den Wyngaert (n 180) 486; Vasiliev, 'Victim Participation Revisited' (n 179) 1133, 1164.

183 Rome Statute (n 69) art 75(2).

${ }^{184}$ Van den Wyngaert (n 180) 481-82; Vasiliev, 'Victim Participation Revisited' (n 179) 1147-63.

185 Van den Wyngaert (n 180) 481-82.
} 
Commentators have criticized both the application process and the participation scheme for victims as inefficient, cumbersome and costly. ${ }^{186}$ They have also argued that victim participation interferes with the accused's right to a fair trial, for two principal reasons: 1) it taxes the already limited resources of defense counsel by requiring counsel to expend time to review victim applications and respond to victim submissions; and 2) it violates equality of arms by pitting the defense against multiple accusers. ${ }^{187}$ At this point, critiques of victim participation are so widespread that, as one commentator concluded, "alarmed accounts outweigh by far the more positive and hopeful ones."188

It is therefore not surprising to find that a number of defense attorneys are also concerned about the practice. Roughly $27 \%$ of respondents stated that victim participation at the ICC violates the rights of the accused, and another $20 \%$ believe that it does so "in some respects." In open-ended responses, attorneys explained that the ICC has not managed victim participation properly and that victim participation exacerbates the imbalance between prosecutorial and defense resources:

$[\mathrm{M}] \mathrm{y}$ experience... is that it is a waste of time to have victims participating directly. Their contribution in the trial is slight - they merely echo the prosecution - and the resources spent on them would be better employed on the defence. Come reparations their role obviously increases. The whole victim issue is a mess in my view - and in the view of many of the judges. ${ }^{189}$

Victims' intervention has been poorly managed. Victims counsel have often misconstrued their role as independent participants in the trial process to protect the rights of victims who deserve to have a voice in the determination of crimes perpetrated against them. Victims may be witnesses for the prosecution as well. That does not make victim counsel associates of the Prosecution in the trial proceedings. Unfortunately victim counsel, and partisan NGO and Special interests purporting to act on behalf victims have often tainted the trial proceedings with the advancement of their activist agenda, making fair trial hard to attain. ${ }^{190}$

It has nearly reached a level of a third 'party' rather than expressing only views and concerns 'where the personal interests of the victims are affected' pursuant to Article 68(3). Meaningful participation has been lost to blanket participation. ${ }^{191}$

Other respondents also complained that the court does not adequately test evidence of victim status or other allegations by victim participants:

The representation for victims prevent $[\mathrm{s}]$ the case proceeding as a normal trial. In effect there are 2 prosecution counsel. The Judges can take into account victims' wishes based upon no supporting evidence. ${ }^{192}$

\footnotetext{
186 Van den Wyngaert (n 180) 481; Vasiliev, 'Victim Participation Revisited' (n 179) 1138-43; Expert Initiative (n 4) 198.

187 Van den Wyngaert (n 180) 495; Vasiliev, 'Victim Participation Revisited' (n 179) 1172; Expert Initiative (n 4) 181.

188 Vasiliev, 'Victim Participation Revisited' (n 179) 1139.

189 Respondent \# 10.

190 Respondent \# 23.

191 Respondent \# 16; see also Respondent \# 14 ("They usually work like a second prosecutor which impinges on the right to equality of arms.").
} 
Non disclosure of details to verify if victims are authentic. No proper review of veracity of victim accounts and no action or prosecution has been undertaken against false claims. Use of intermediary organizations continues unsupervised. ${ }^{193}$

In a subsequent question, asking respondents to state "the top three procedural reforms that the International Criminal Court ought to institute," three respondents suggested that the ICC should limit victim participation-for example, by not allowing victims to take part in the pre-confirmation stage or by limiting their participation to the reparation stage. ${ }^{194}$ Victim participation therefore appears to be an important reform priority among defense attorneys, just as it is among ICC commentators and judges.

\section{Institutional Support for the Defense}

Respondents also expressed the view that the defense needs better institutional support at the ICC, though they disagreed on the form that this support should take. At present, counsel are supported by two different organs of the ICC-the Counsel Support Section (CSS) and the Office of Public Counsel for the Defense (OPCD). The CSS maintains the list of counsel, administers the legal aid scheme, and helps counsel with technical and logistical issues. ${ }^{195}$ The OPCD provides legal research and advice to defense teams, stands in as duty counsel for defendants at their initial appearance, and represents the defense internally and externally. ${ }^{196}$ Although both sections operate formally under the auspices of the Registry, the Regulations of the Court provide for the independence of the OPCD, but not the CSS. ${ }^{197}$

At first blush, the institutional structure of the ICC appears generous and fully capable of advancing defense interests. In practice, a different picture emerges. While the OPCD is independent, its small staff and its exclusion from certain decision-making groups within the court prevent it from fully representing defense interests at the ICC. ${ }^{198}$ Furthermore, under a reform project launched by the ICC Registrar, the CSS and OPCD are soon to be merged into one Defense Office that will be part of the Registry, with a reduced staff and without independence from the Registry. ${ }^{199}$ To address concerns about the lack of independence of the new Defense Office, counsel recently created a self-governing Association of Defense Counsel. However, this Association is not an organ of the ICC and may not be fully effective in advocating for defense positions in key ICC decision-making mechanisms.

\footnotetext{
192 Respondent \# 21.

193 Respondent \# 13.

194 Respondents \# 10; \# 14; \# 21.

195 IBA, Counsel Matters (n 179) 22.

196 Philipp Müller, 'Promoting Justice Between Independence and Institutional Constraints: The Role of the Office of the Public Counsel of the Defence at the ICC' in Mayeul Hiéramente and Patricia Schneider (eds), The Defence in International Criminal Trials 245, 249-60 (Nomos 2016).

197 ICC Regulations of the Court (n 41) reg 77.

198 Müller (n 196) 258-60, 268; Expert Initiative (n 4) 203.

199 Müller (n 196) 263 (arguing that the restructured defense office "will cease to be independent and become part of the hierarchy of the Registry both in legal and practical terms").
} 
In light of the significant restructuring of defense support mechanisms within the court, the survey asked counsel whether they believe that the ICC should reform the structure or the mandate of the CSS or the OPCD. A majority of respondents supported some type of reform, but their views differed widely on the shape that reform should take. A number of respondents expressed general satisfaction with the work of the OPCD (some also included the CSS), ${ }^{200}$ but many argued that the defense needs a stronger office that is entirely independent from the Registrar.

A few thought that the proposed independent bar association for ICC defense attorneys is a good step in that direction:

We desperately need an independent ICC Bar Association for all Counsel who are practising under the ICC Code of Professional Conduct., which will be now founded end of June 2016. This ICCBA shall (and will finally) replace the OPCD as well as OPCV which will not be necessary any longer. In no national system we have comparable Offices since we have competent and experienced Bar Associations. CSS as a service unit will always be necessary in a way or another. ${ }^{201}$

But others were more skeptical that the Bar Association was the proper solution, ${ }^{202}$ and they called instead for an independent defense section-perhaps a reformed OPCDwithin the ICC itself. ${ }^{203}$ As one opined:

Preliminary discussions of a Defence Organ should occur as this will be the only true way to fully achieve structural equality of arms and respect the Defence as a party to the proceedings. If such possibility is totally foreclosed at this time, the mandate of the Office of Public Counsel for the Defence should be strengthened to allow it to better serve both the Court and the Defence teams in its capacity as an independent office. The Counsel Support Section should receive any resources it needs to fully perform core duties to provide legal aid and resources to not only the Defence, but also the Victims (LRVs), Governments' counsel, witness' counsel and other independent counsel before the Court. ${ }^{204}$

More broadly, in discussing ideas for procedural reform, a few respondents opined that the court should consult the defense more regularly on procedural and institutional questions. ${ }^{205}$ This sentiment was echoed in public comments by defense attorneys on the

\footnotetext{
200 See, eg, Respondent \# 21 (“OPCD provides an excellent service. The CSS is largely invisible to the Defence.”); Respondent \# 22 (“CSS as a service unit will always be necessary in a way or another.”).

201 Respondent \# 22.

202 See, eg, Respondent \# 18(“'This is a very difficult matter. Not all new experiments are always good. not sure whether the newly established ICC Bar is the solution. Maybe worth some re-organisations, the current structure could be the best under the circumstances.").

${ }^{203}$ See, eg, Respondent \# 15 ("Yes. Absolutely. The Defense Section should be independent from the Registrar- Now!"); Respondent \# 19 (“CSS should either be more of an ally with Defense or have less influence. OPCD should be independent.").

204 See, eg, Respondent \# 16.

205 Respondent \# 16 ("Effective involvement of the Defence point of view in Court-wide planning and advancement (especially in textual amendments and budgetary or policy decisions). This would, in particular, allow address of many post-acquittal/post-convictions that have arisen and those yet to come."); Respondent \# 23 ("grant the defence institutional recognition").
} 
Registry's decision to reduce legal aid payments, which was made after minimal consultation and opportunity for comment by the defense. ${ }^{206}$

Respondents' view that the ICC should create an independent defense organ within the Court has found support among outside observers of the Court. Fedorova has argued that establishing an independent defense organ at the ICC would help "to eradicate any perception of inequality and to secure the rights of the defence more broadly." ${ }^{207}$ Likewise, the Expert Initiative on Promoting Effectiveness at the ICC has called on states to "consider creating an independent Defence Office as a separate organ of the Court with its own Head and with a mandate similar in kind and nature to the mandate of the Defence Office before the Special Tribunal for Lebanon." 208

If the defense is a formal ICC organ, it can address cooperation requests directly to states, improving the odds of such requests being honored. ${ }^{209}$ At present, the defense must always request judicial assistance to obtain cooperation from domestic authorities. ${ }^{210}$ As the Assembly of States Parties has recognized, "It is burdensome for the defence to approach Chambers for a Court order each time they need a particular piece of information, and in most cases Chambers would request that the defence first approach the authorities in question. This leads to very slow turn-around time for this type of cooperation...." 211 For all these reasons, the International Bar Association has also advocated for the establishment of an independent defense office, which "would reflect, at an institutional level, the principle of equality arms. ... It would allow the defence office to justify its own budget and would significantly ameliorate many of the difficulties that the defence counsel currently face, including obtaining state cooperation."212

\section{8. $\quad$ Procedural Consistency}

Another theme that emerged in the survey responses was a desire for greater consistency in judicial decisionmaking at the ICC. For example, when the survey asked respondents about top three procedural reforms that the ICC ought to institute, a few identified consistency as a priority. As one person opined, the Court should "choose a procedural system and stick to it." ${ }^{, 13}$ The same person further stated that proceedings should be defined "in the ICC text not in the jurisprudence." 214 The desire for greater predictability was shared by another respondent as well: "[I would propose] Consistency of trial procedure. While there is certain direction to address this in the Chambers Practice Manual, trial procedure can still benefit from more consistency from Chamber to Chamber and be

\footnotetext{
206 See Hooper (72) 1-2; Keïta (n 95) 3.

${ }^{207}$ Fedorova (n 102) 451.

208 Expert Initiative (n 4) 36.

${ }^{209}$ Fedorova (n 102) 451.

210 See Rome Statute (n 69) art 57(3)(b).

211 ibid 188 (citing ICC, Assembly of States Parties, Report of the Bureau on Cooperation, ICC-ASP/6/21 (19

October 2007) [33], adopted by the Assembly of States Parties, Omnibus Resolution, ICC-ASP/6/Res.2 (14

December 2007)).

212 IBA, Fairness at the International Criminal Court (n 68) 35.

213 Respondent \# 15.

214 ibid.
} 
solidified in the Rules or Regulations." ${ }^{215}$ Other comments likewise lamented inconsistent rules with respect to procedures such as the confirmation and recharacterization of charges. ${ }^{216}$

The inconsistent procedural rulings of ICC Pre-Trial and Trial Chambers are widely acknowledged. While some scholars have celebrated this diversity of approaches, others have criticized it as unfair and inefficient. ${ }^{217}$ Like the defense respondents cited here, the latter have argued that Chambers should adopt practice manuals on important procedural issues like discovery and that the Appeals Chamber should intervene more regularly to resolve inconsistent judgments on procedural matters. ${ }^{218}$

\section{The Future of Managerial Judging and Procedural Fairness at the ICC}

Efficiency has become a common refrain at ICC Assembly of States Parties meetings, and the court itself is actively discussing ways in which it can streamline proceedings. Yet in survey responses, defense attorneys note that, for the most part, judges have not elevated efficiency above other values in the criminal process. For example, judges have not unduly limited defendants' rights to make a statement, to present witnesses, or to question adverse witnesses. They have not used informal sanctions, such as dismissing defense motions as "frivolous" or "delay tactics," to expedite the process. Nor have they pressured the parties to negotiate cases or the defense to disclose its strategy early in the case. To the extent that a focus on efficiency has affected defense representation, this has been primarily the result of administrative and funding decisions made by the Registry and States Parties, not by judges. ${ }^{219}$

While defense attorneys do not believe that judicial managerialism at the ICC is threatening defense rights, they express concern about other procedural decisions. In the defense's view, judges have not done enough to filter out unsubstantiated charges, ensure prompt and comprehensive disclosure, permit interlocutory appeals, or limit victim participation. More broadly, defense attorneys believe that the court could do more to provide equality of arms between the parties. Similar critiques have been made by academic commentators and even ICC judges and are therefore not idiosyncratic or overly partisan views held only by the defense.

To address some of the problems identified by defense attorneys, such as the need for more generous support for defense investigations, the court would need to invest additional resources. Given the emphasis on cost-cutting at the ASP and the underfunding of other ICC divisions, including the prosecution and victim support sections, it is unlikely

\footnotetext{
215 Respondent \# 16.

$216 \mathrm{ibid}$ ("At this time, charging instruments vary from case to case and this provides insufficient notice of charges to the defendants which is in violation of rights. In addition, the proliferation of the use of Regulation 55 to notice additional modes of liability and other charges even prior to trial has rendered the process of CoC nearly meaningless (i.e. modes of liability litigated and not found as 'charged' modes of liability in the CoC process are later noticed via Regulation 55).”).

217 Vasiliev, 'Victim Participation Revisited' (n 185). [add cites]

218 Expert Initiative (n 4) 34, 209-10.

${ }^{219}$ Defense attorneys did state that judges have unduly limited their ability to file interlocutory appeals, which is likely explained by efficiency concerns.
} 
that the court would significantly increase legal aid in the near future. As respondents asserted, however, the court could take other measures that help promote equality of arms between the parties while not consuming additional resources. In fact, many of the measures proposed by defense attorneys-filtering out weak charges more aggressively, ordering earlier and broader disclosure by the prosecution, and limiting victim participation-can be pursued consistently with an emphasis on efficiency.

Consider first the idea that judges could do more to manage the confirmation process and filter out unsubstantiated charges. A number of commentators have put forth similar proposals to promote efficiency at the ICC. For example, two recent expert reports on expediting ICC proceedings advocated that Chambers should "more actively seek to control and regulate the process of confirmation." 220 One of these reports also called on the prosecutor to "put in place a stricter and more critical reviewing process." 221 To allow for more effective judicial review of the charges, commentators have also urged the prosecution to develop a classification system for investigative paperwork. ${ }^{222}$ Some judges and scholars have further opined that, to facilitate the review process and streamline proceedings, the prosecution should conclude investigations before the confirmation stage. ${ }^{223}$ If managerial judging takes this direction with respect to the confirmation process, it would place a heavier burden on the prosecution and benefit the defense. ${ }^{224}$

Of course, reform of the confirmation process in the name of efficiency could take other shapes, which would not advance equality of arms. For example, the Court could limit the presentation of witnesses at confirmation and encourage the parties to rely more heavily on written evidence and summaries of evidence. ${ }^{225}$ This would restrict the defense's ability to challenge the prosecution evidence and to contest the charges during confirmation. It would also delay disclosure of most evidence until after confirmation, leaving defense teams even less time to respond to it.

Another reform suggested by defense attorneys-reform of the disclosure processcould also help advance equality of arms while simultaneously enhancing efficiency. Broad prosecutorial disclosure can help to offset the limited investigative resources of the defense and ensure the fairness of the proceedings. It can also minimize disclosure disputes and failures, which have led to enormous delays at the ICC. Commentators have argued that, to expedite proceedings, judges must push for earlier and broader disclosure and adopt uniform standards with respect to disclosure and redactions. ${ }^{226}$ Some have also argued that Chambers should require the prosecution to identify how each piece of disclosed evidence relates to the charges. This would, in their view, "expedite proceedings and [ prepare properly for the confirmation hearing," but also "ensure that the defence [is] prepared under satisfactory

\footnotetext{
220 Expert Initiative (n 4) 95.

221 ibid 96.

222 ibid 10.

223 See, eg, Kaul (n 8) 111; Expert Initiative (n 4) 66; WCRO Expediting Proceedings Report (n 4) 17.

${ }^{224}$ Because such measures may simply shift the burden to the prosecution, further study is needed to determine whether they will in fact advance the court's efficiency.

${ }^{225}$ Megan Fairlie, The ICC Can Still Learn from the History of Written Witness Statements in International Criminal Trials...but Will It? (manuscript on file with author); Expert Initiative (n 4) 23; WCRO Confirmation of Charges (n 44) 90.

226 See, eg, Expert Initiative (n 4) 15.
} 
conditions." 227 Likewise, some experts have urged prosecutors to apply a liberal approach to disclosure and adopt a presumption of disclosing all documents, unless a good reason for withholding exists. ${ }^{228}$

How successfully the idea of liberal disclosure can be implemented at the ICC, however, remains an open question. A main source of disclosure delay has been the difficulty of ensuring witness protection, which remains a vexing problem. ${ }^{229}$ In light of these challenges, an efficiency-oriented judge may choose to postpone ordering disclosure that is not strictly related to the confirmation of charges until after the confirmation hearing, so as to avoid the delays associated with redactions and other forms of witness protection. ${ }^{230}$ It is therefore possible to envision a managerial judge streamlining disclosure in a way that undercuts equality of arms. At this point, however, most commentators tend to agree with the defense that more liberal disclosure at the ICC is both feasible and likely to expedite proceedings. $^{231}$

Another area of concern to the defense is the broad interpretation of victim participation in ICC proceedings. Many defense attorneys dislike the current model of victim participation because it requires the defense to respond to multiple opponents at the same time and drains defense resources. Many also believe that victim participation has become too unwieldy and interferes with the right to an expeditious trial, and this is a concern shared by outside commentators and ICC judges. Here again, the proposals for limiting victim participation in the proceedings - for example, streamlining the victim application process, restricting the modes of victim participation, or more drastically, limiting victims' involvement to just the reparations stage-may help bring the process closer to procedural parity between the defense and the prosecution, while also expediting the proceedings and reducing costs.

In brief, should judges take measures to expedite proceedings at the ICC, a number of these measures could benefit the defense. Contrary to standard scholarly predictions, at least some forms of managerial justice could be reconciled with equality of arms. As the push for efficiency unfolds, we are likely to see the prosecutor and the defense each advocating for judges to manage the proceedings in a fashion that does not impinge on their respective rights and interests. ${ }^{232}$ While standard theory predicts that the defense has the most to lose from a managerial approach to judging, the early experience of the ICC suggests that the picture is not so straightforward. Managerial judging, if coupled with a concern for equality of arms, can limit prosecutorial activity and aid the defense, while also ensuring an efficient process.

\footnotetext{
${ }^{227}$ Van der Vyver (n 11) (citing Bemba (n 154) [72]). It remains highly disputed whether these in-depth analysis charts in fact advance efficiency.

${ }_{228}$ Expert Initiative (n 4) 105.

${ }^{229}$ WCRO Confirmation of Charges (n 44) 121; Whiting, 'Dynamic Investigative Practice' (n 45) 179-82.

${ }^{230}$ cf WCRO Confirmation of Charges (n 44) 32.

${ }^{231}$ Expert Initiative (n 4) 105 [add cites].

232 See Jackson \& M’Boge (n 4) 965 (noting that prosecutors, judges, and defense attorneys had different ideas on how managerial judging "should be manifesting itself in the reality of the operations of the international criminal bench").
} 